\title{
Chemical and isotopic composition of secondary organic aerosol generated by $\alpha$-pinene ozonolysis
}

\author{
Carl Meusinger ${ }^{1, \mathrm{a}}$, Ulrike Dusek ${ }^{2,3}$, Stephanie M. King ${ }^{1,4}$, Rupert Holzinger ${ }^{2}$, Thomas Rosenørn ${ }^{1,5}$, Peter Sperlich ${ }^{6, \mathrm{~b}}$, \\ Maxime Julien $^{7}$, Gerald S. Remaud ${ }^{7}$, Merete Bilde ${ }^{1, c}$, Thomas Röckmann ${ }^{2}$, and Matthew S. Johnson ${ }^{1}$ \\ ${ }^{1}$ Department of Chemistry, University of Copenhagen, 2100, Copenhagen $\emptyset$, Denmark \\ ${ }^{2}$ Institute for Marine and Atmospheric research Utrecht (IMAU), Utrecht University, 3584 CC, Utrecht, the Netherlands \\ ${ }^{3}$ Centre for Isotope Research, Energy and Sustainability Research Institute Groningen, 9747 AG Groningen, the Netherlands \\ ${ }^{4}$ now at: Haldor Topsøe A/S, 2800, Kgs. Lyngby, Denmark \\ ${ }^{5}$ Infuser ApS, 2200, Copenhagen N, Denmark \\ ${ }^{6}$ Max-Planck Institute for Biogeochemistry, 07745 Jena, Germany \\ ${ }^{7}$ CEISAM, UMR CNRS6230, BP 92208, Nantes 44322 cedex 3, France \\ ${ }^{a}$ now at: Airlabs, 2200, Copenhagen N, Denmark \\ ${ }^{b}$ now at: National Institute of Water and Atmospheric Research (NIWA), Wellington 6021, New Zealand \\ ${ }^{c}$ now at: Aarhus University, Department of Chemistry, 8000 Aarhus C, Denmark
}

Correspondence to: Carl Meusinger (c.meusinger@gmail.com)

Received: 17 February 2016 - Discussion started: 19 February 2016

Revised: 21 March 2017 - Accepted: 20 April 2017 - Published: 29 May 2017

\begin{abstract}
Secondary organic aerosol (SOA) plays a central role in air pollution and climate. However, the description of the sources and mechanisms leading to SOA is elusive despite decades of research. While stable isotope analysis is increasingly used to constrain sources of ambient aerosol, in many cases it is difficult to apply because neither the isotopic composition of aerosol precursors nor the fractionation of aerosol forming processes is well characterised. In this paper, SOA formation from ozonolysis of $\alpha$-pinene an important precursor and perhaps the best-known model system used in laboratory studies - was investigated using position-dependent and average determinations of ${ }^{13} \mathrm{C}$ in $\alpha$-pinene and advanced analysis of reaction products using thermal-desorption proton-transfer-reaction mass spectrometry (PTR-MS). The total carbon (TC) isotopic composition $\delta^{13} \mathrm{C}$ of the initial $\alpha$-pinene was measured, and the $\delta^{13} \mathrm{C}$ of the specific carbon atom sites was determined using positionspecific isotope analysis (PSIA). The PSIA analysis showed variations at individual positions from -6.9 to $+10.5 \%$ relative to the bulk composition. SOA was formed from $\alpha$-pinene and ozone in a constant-flow chamber under dark, dry, and low- $\mathrm{NO}_{x}$ conditions, with $\mathrm{OH}$ scavengers and in the absence of seed particles. The excess of ozone and long residence
\end{abstract}

time in the flow chamber ensured that virtually all $\alpha$-pinene had reacted. Product SOA was collected on two sequential quartz filters. The filters were analysed offline by heating them stepwise from 100 to $400^{\circ} \mathrm{C}$ to desorb organic compounds that were (i) detected using PTR-MS for chemical analysis and to determine the $\mathrm{O}: \mathrm{C}$ ratio, and (ii) converted to $\mathrm{CO}_{2}$ for ${ }^{13} \mathrm{C}$ analysis.

More than 400 ions in the mass range $39-800 \mathrm{Da}$ were detected from the desorbed material and quantified using a PTR-MS. The largest amount desorbed at $150{ }^{\circ} \mathrm{C}$. The $\mathrm{O}: \mathrm{C}$ ratio of material from the front filter increased from 0.18 to 0.25 as the desorption temperature was raised from 100 to $250^{\circ} \mathrm{C}$. At temperatures above $250^{\circ} \mathrm{C}$, the $\mathrm{O}: \mathrm{C}$ ratio of thermally desorbed material, presumably from oligomeric precursors, was constant. The observation of a number of components that occurred across the full range of desorption temperatures suggests that they are generated by thermal decomposition of oligomers.

The isotopic composition of SOA was more or less independent of desorption temperature above $100^{\circ} \mathrm{C}$. TC analysis showed that SOA was enriched in ${ }^{13} \mathrm{C}$ by $0.6-1.2 \%$ relative to the initial $\alpha$-pinene. According to mass balance, gas-phase products will be depleted relative to the initial 
$\alpha$-pinene. Accordingly, organic material on the back filters, which contain adsorbed gas-phase compounds, is depleted in ${ }^{13} \mathrm{C}$ in TC by $0.7 \%$ relative to the initial $\alpha$-pinene, and by $1.3 \%$ compared to SOA collected on the front filter. The observed difference in ${ }^{13} \mathrm{C}$ between the gas and particle phases may arise from isotope-dependent changes in the branching ratios in the $\alpha$-pinene $+\mathrm{O}_{3}$ reaction. Alternatively, some gasphase products involve carbon atoms from highly enriched and depleted sites, as shown in the PSIA analysis, giving a non-kinetic origin to the observed fractionations. In either case, the present study suggests that the site-specific distribution of ${ }^{13} \mathrm{C}$ in the source material itself governs the abundance of ${ }^{13} \mathrm{C}$ in SOA.

\section{Introduction}

Secondary organic aerosol (SOA) is formed in the atmosphere by oxidation of volatile organic compounds (VOCs). SOA contributes significantly to atmospheric aerosol and impacts climate, air quality, and health (Stocker et al., 2013; Hänninen et al., 2004; Dockery et al., 1993; Andreae and Crutzen, 1997). Despite their impacts the mechanisms of SOA formation and processing are poorly understood and significant discrepancies between model predictions and observations are common.

Stable carbon isotopes are increasingly used to investigate aerosols in the atmosphere. Isotopic analysis holds the promise of clearly identifying SOA sources and atmospheric transformations, as long as we know enough details, such as the isotopic composition of the source emissions, the kinetic fractionations occurring in oxidation reactions, and the isotope effects in phase partitioning. The ability to distinguish individual sources, including marine aerosol (Turekian et al., 2003; Ceburnis et al., 2011) and biomass burning (Kirillova et al., 2013), by isotope measurements has been particularly useful when it comes to source apportionment of ambient aerosol (e.g. Sakugawa and Kaplan, 1995; Narukawa et al., 2008; Turekian et al., 2003; Widory et al., 2004; Ho et al., 2006; Huang et al., 2006; Fisseha et al., 2009; Kirillova et al., 2013; Ceburnis et al., 2011; Fu et al., 2012; Miyazaki et al., 2012; O’Dowd et al., 2014; Masalaite et al., 2015).

In some other cases, measurements of the isotopic composition of SOA have yielded intriguing and/or contradictory results: (Irei et al., 2014) found that SOA formation from oxidation of volatile organics lead to depletion in ${ }^{13} \mathrm{C}$ in the low-volatile fraction of the aerosol. (Fu et al., 2012), however, reported isotopic enrichments in ambient SOA that are distinguishable between biomass burning and primary emissions, possibly hinting at the oxidation of biogenic VOCs.

Recent technical advances have made it possible to quantify isotopic enrichments at specific sites within molecules, in addition to the traditional determination of the enrichment of the sample itself (Bayle et al., 2014b). This development makes possible new analyses of chemical mechanisms and transformations in the environment. Consider a chemical reaction that goes to completion to give a variety of products. The atoms of a reagent are distributed among the products, depending on the branching ratios for the different reaction channels. The branching ratios may themselves be isotopedependent. For the formation of SOA from a VOC precursor, the isotopic enrichments or depletions that are observed in the SOA arise from the contributions of many oxidation products. Mass balance implies that the complimentary pattern will be observed in gas-phase products. Many interesting research questions arise from the application of site-specific isotopic analysis to atmospheric science. Perhaps the most important question is whether observed average composition of the SOA is due to the isotope dependent changes in product branching ratios within the reaction mechanism or due to the site-specific enrichments of the reagent.

Isotopic substitution can cause reactions to be faster or slower than for the un-substituted case, kinetically fractionating the isotopes and leading to isotopic enrichment or depletion in the products. This is known as the kinetic isotope effect (KIE). If a reaction leads to a single product, the product may initially have a different abundance; but due to the law of mass balance, the product will achieve the same abundance as the reagent as the reaction goes to completion. If a reaction has multiple product channels, enrichment or depletion will occur if there are isotope-dependent changes in the product branching ratios.

The ozonolysis of $\alpha$-pinene is often used as a test system for formation of SOA; it is fairly well studied. Figure 1 shows a reaction scheme for $\alpha$-pinene ozonolysis, based on the "Master Chemical Mechanism" (MCMv3.1) as described by (Camredon et al., 2010). In the first step, ozone adds into the double bond of the molecule, resulting in two branches depending on the usual Criegee mechanism. These two branches proceed by stabilisation, subsequent fragmentation and isomerisation, and subsequent reaction with $\mathrm{RO}_{2}, \mathrm{HO}_{2}$, and $\mathrm{H}_{2} \mathrm{O}$ to yield a wide range of oxidation products from $\mathrm{CO}, \mathrm{HCHO}$, and acetone, to many larger oxidised low volatile molecules like pinic acid and pinonic acid and pinonaldehyde. The figure shows only formation of first-generation products. Further reactions including dimer formation (Kristensen et al., 2016) and oligomerisation reactions are not shown.

Generally, reactions involved in atmospheric VOC oxidation fall into three categories: functionalisation, fragmentation, and oligomerisation (Kroll and Seinfeld, 2008; Rudich et al., 2007; Chacon-Madrid and Donahue, 2011). The volatility (Donahue et al., 2006; Jimenez et al., 2009) and oxygen-to-carbon ratio, O:C (Donahue et al., 2011; Kroll et al., 2011), of involved species allow for the characterisation of these processes. The characteristics of the three types of atmospheric VOC reactions and current understanding of how they contribute to isotopic fractionation (Kirillova et al., 2013, 2014) are summarised as follows: 


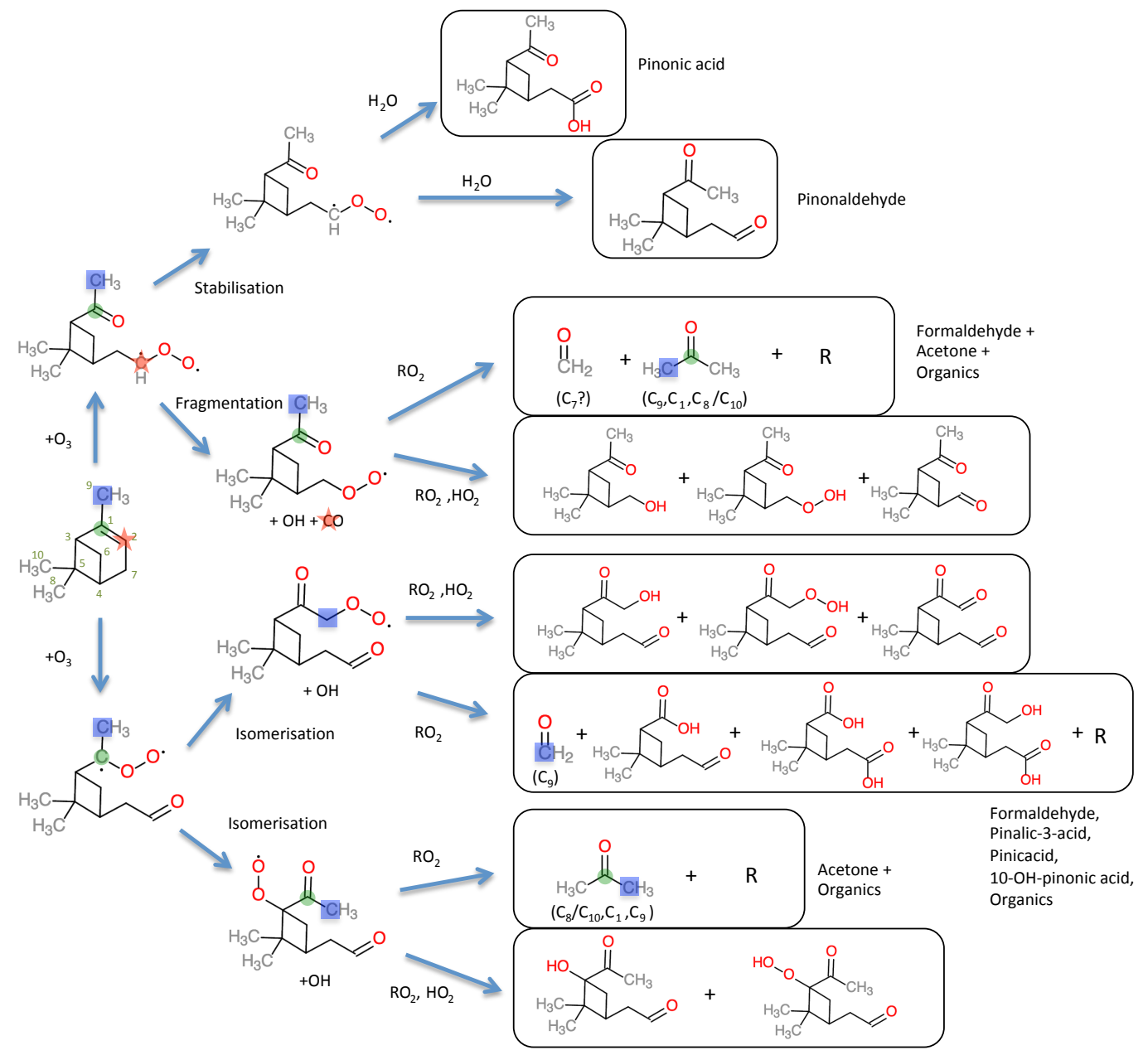

Figure 1. Reaction scheme of $\alpha$-pinene ozonolysis, based on (Camredon et al., 2010), using the reaction mechanism of MCMv3.1. The boxes show first-generation products, while subsequent dimer formation and oligomerisation are not shown. The $\mathrm{O}: \mathrm{C}$ ratio typically increases as oxidation proceeds (i.e. oxygen addition via functionalisation). Large, oxygenated product compounds (e.g. pinonic acid, pinonaldehyde) have lower vapour pressures and partition to the particle phase. Small, volatile products including $\mathrm{HCHO}$, acetone, and CO result from fragmentation processes and partition to the gas phase. The coloured symbols highlight how the parent $\alpha$-pinene's atoms (denoted in brackets) can form small reaction products including $\mathrm{CO}, \mathrm{HCHO}$, and acetone. The symbol colours were chosen based on the heat map in Fig. 7.

- Functionalisation describes the addition of oxygenated functional groups to the parent compound. A typical example is the first reaction step in VOC oxidation. In these reactions, products are less volatile and have higher $\mathrm{O}: \mathrm{C}$ ratios than the parent compound. Functionalisation is typically accompanied by normal kinetic fractionation leading to oxidation products depleted in ${ }^{13} \mathrm{C}$ (Rudolph and Czuba, 2000; Iannone et al., 2010; Gensch et al., 2011). In the present study, the parent compound $\alpha$-pinene was fully oxidised, leaving no isotopic imprint on its products (the KIE of $\alpha$-pinene ozonolysis has not been reported to date).

- Fragmentation describes cleavage of carbon-carbon bonds, possibly followed by addition of oxygen to the fragments. Fragmentation reactions in the condensed phase can result in molecules that are small, like $\mathrm{CO}_{2}$ and $\mathrm{CH}_{2} \mathrm{O}$, having higher volatilities than the parent compound and possibly escaping to the gas phase (Kroll et al., 2009). Fragmentation may enrich the aerosol in ${ }^{13} \mathrm{C}$ through normal kinetic fractionation: when some of the depleted reaction products are lost to the gas phase, the remaining aerosol phase will be enriched (Aggarwal and Kawamura, 2008). The $\mathrm{O}: \mathrm{C}$ ratio of the products is often higher than for the parent VOC and is typically highest for compounds remaining in the aerosol phase. During ozonolysis of monoterpenes, both functionalisation and fragmentation occur simultaneously (ChaconMadrid and Donahue, 2011), as also shown in Fig. 1. This increases the $\mathrm{O}: \mathrm{C}$ ratio but the overall effect on the isotopic balance is not well established. 
- Oligomerisation (sometimes also referred to as accretion) describes the building of larger organic structures from monomers, often in the aerosol phase (Kalberer et al., 2004, 2006; Hallquist et al., 2009). One mechanism is that oxygenated organics become linked by dehydration reactions, and this lowers the $\mathrm{O}: \mathrm{C}$ ratio. The formation of complex organic mixtures in the aerosol phase (Cappa et al., 2008) is expected to show similar characteristics in vapour pressure and $\mathrm{O}: \mathrm{C}$ ratio. The influence of oligomerisation on the isotopic composition of the aerosol is not clear, but likely small.

Chemical analysis based on proton-transfer-reaction mass spectrometry has proven very useful in ambient and laboratory studies investigating aerosol and gas-phase compounds and their properties (e.g. Holzinger et al., 2010a, b; Shilling et al., 2008; Presto and Donahue, 2006). Advantages of the technique include the soft ionisation, high sensitivity, wide range of detectable compounds, and the possibility of quantifying them. In addition, using a proton-transfer-reaction time-of-flight mass spectrometer (PTR-ToF-MS, shortened to PTR-MS for the remainder of the article) allows chemical characterisation and identification of compounds and estimation of the $\mathrm{O}: \mathrm{C}$ ratio.

Position-specific isotope analysis (PSIA) of the initial reactant offers a detailed description of bulk isotopic data by mapping the intra-molecular isotope distribution. PSIA by ${ }^{13} \mathrm{C}$ isotope ratio monitoring by nuclear magnetic resonance (NMR) (irm- ${ }^{13} \mathrm{C}$ NMR) has proven valuable in interpreting a number of (bio)chemical (Bayle et al., 2014a; Botosoa et al., 2009a; Gilbert et al., 2011, 2012) and physical-chemical processes such as distillation and sorption (Botosoa et al., 2008, 2009b; Höhener et al., 2012), leading to a deeper understanding of the underlying phenomena causing isotope fractionation in nature. It is widely understood that the enrichment or depletion of a product depends on the enrichment of the starting material, the isotopic fractionation occurring in the mechanism of its formation, and the extent of reaction. Using PSIA, we can take this analysis one step further: the enrichment of a product will depend on the position-dependent enrichments of the atoms from which it is formed. For example the ozonolysis mechanism transfers the $\mathrm{C} 9$-atom in $\alpha$ pinene into several small, volatile products (see blue squares in Fig. 1). If the C9-position was depleted in ${ }^{13} \mathrm{C}$, the gasphase products containing this atom would be depleted, and the SOA correspondingly enriched, as long as the positiondependent effect was stronger than kinetic isotope effects.

In this study we have designed an experiment to use a combination of position-specific, sample-average, and moleculeaverage isotopic abundance data to investigate the formation of SOA from the ozonolysis of $\alpha$-pinene. Due to mass balance, the enrichment (or depletion) in SOA must be balanced by depletion (or enrichment) in gas-phase products, since in our experiment $\alpha$-pinene ozonolysis has gone to completion. However, since the reaction mechanism is not known in de- tail and cannot be determined from our experiment, we are left to interpret an incomplete case. One instructive limiting case is to ask which atoms in $\alpha$-pinene are transformed into known gas-phase products. We argue that the observed isotope distribution in SOA is likely balanced by the opposite pattern in the gas-phase products, and that this pattern could be produced by site-specific enrichments in the starting material and current incomplete knowledge of the reaction mechanism alone, aside from whatever effects isotopic substitution may have on product branching ratios. Thus, we make the case that position-sensitive isotopic enrichments and depletions, and not just bulk KIEs, are an important element of explaining field observations, especially for natural products which are known to have, as a group, significant site-specific enrichments and depletions relative to fossil and/or synthetic compounds. The goal of this study is to provide detailed isotopic and chemical characterisation of newly formed $\alpha$ pinene SOA and to shed light on the mechanisms that govern isotopic fractionation in the formation of fresh SOA.

\section{Material and methods}

\subsection{Chemical compounds used}

Chamber experiments were performed using the following chemicals: $(+)-\alpha$-pinene (Aldrich, $>99 \%$, batch no. 80796DJV), 1-Butanol (Sigma-Aldrich, $>99.4 \%$ ) and cyclohexane (Labscan, $99.5 \%$ ). PSIA was performed on several samples of $\alpha$-pinene from Sigma-Aldrich (different lot), Acros Organics, Merck, and Alfa Aesar; see Table 1. The batch of $\alpha$-pinene used in the chamber experiments could not be analysed using PSIA, because the manufacturer does not supply it anymore.

\subsection{Chamber design and characteristics}

A new aerosol smog chamber was built in Copenhagen based on a steady-state design (King et al., 2009; Shilling et al., 2008; Kleindienst et al., 1999). It consists of a $4.5 \mathrm{~m}^{3}$ teflon bag (the volume / surface ratio is $0.275 \mathrm{~m}$ ) mounted inside a temperature-controlled insulated room of walk-in size (Viessmann A/S); see Fig. S1 in the Supplement. While details can be found in Sect. S1, chamber operation is briefly summarised here. The chamber was operated in a constantflow mode: dry air and reactants were constantly flushed into the chamber using mass flow controllers. A syringe pump (NE-300, New Era Pump Systems Inc.) continuously injected a mixture of $\alpha$-pinene and 1-butanol or a mixture of $\alpha$ pinene and cyclohexane into a warmed glass bulb. 1-butanol and cyclohexane were used as $\mathrm{OH}$ scavengers and the mixing ratio between $\alpha$-pinene and the $\mathrm{OH}$ scavenger was $1: 600$ $(v / v)$. A small flow of clean, dry air $\left(0.1 \mathrm{~L} \mathrm{~min}^{-1}\right)$ directed over a Hg lamp emitting UV light (model 600, Jelight company inc.) generated ozone which was fed into the chamber separately. 
Table 1. Manufacturer information and isotopic composition of $\alpha$-pinene samples. Position-specific isotopic fractionation is given as isotopic difference, $\Delta_{i}\left({ }^{13} \mathrm{C}\right)=\delta_{i}\left({ }^{13} \mathrm{C}\right)-\delta_{\mathrm{TC}}^{\circ j}\left({ }^{13} \mathrm{C}\right)$, of individual $\mathrm{C}$ atoms $(i)$ in $\alpha$-pinene sample $j$ with bulk isotopic composition $\delta_{\mathrm{TC}}^{\circ j}\left({ }^{13} \mathrm{C}\right)$. Listed are the means of five measurements. See inserted figure for numbering of $\mathrm{C}$ atoms. Sample 1 was used in the chamber experiments, but PSIA could not be performed as the sample was no longer available.

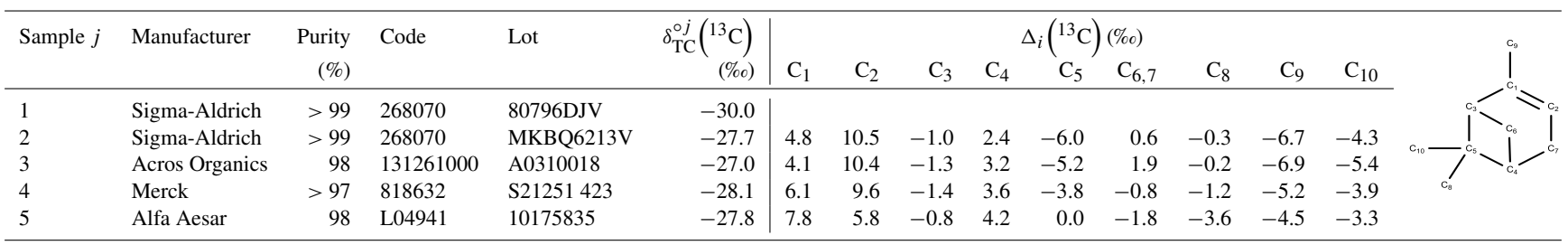

Table 2. Overview of $\alpha$-pinene $\left(\delta_{\mathrm{TC}}^{\circ 1}\left({ }^{13} \mathrm{C}\right)=(-29.96 \pm 0.08) \%\right.$ ) ozonolysis experiments using 1-butanol (B) or cyclohexane $(\mathrm{C})$ as $\mathrm{OH}-$ scavenger. Filter IDs are explained in the text. The sampling time, $t$, and the sampled volume, $V$, are given. Isotopic data at $100{ }^{\circ} \mathrm{C}$ and $150{ }^{\circ} \mathrm{C}$ and for total carbon (TC) are given as $\Delta\left({ }^{13} \mathrm{C}\right)=\delta\left({ }^{13} \mathrm{C}\right)-\delta_{\mathrm{TC}}^{\circ 1}\left({ }^{13} \mathrm{C}\right)$. The total aerosol mass loading as detected by PTR-MS, $M_{\text {total }}^{\text {PTR-MS }}$, is listed next. The last column lists the measured $\mathrm{O}: \mathrm{C}$ ratio averaged over all desorption temperatures.

\begin{tabular}{|c|c|c|c|c|c|c|c|c|}
\hline Experiment & Filter ID & $t(\mathrm{~h})$ & $V\left(\mathrm{~m}^{3}\right)$ & $100^{\circ} \mathrm{C}$ & $\begin{array}{c}\Delta\left({ }^{13} \mathrm{C}\right)(\% \circ) \\
150{ }^{\circ} \mathrm{C}\end{array}$ & $\mathrm{TC}$ & $M_{\text {total }}^{\mathrm{PTR}-\mathrm{MS}}\left(\mu \mathrm{g} \mathrm{m}^{-3}\right)$ & $\mathrm{O}: \mathrm{C}$ \\
\hline \multirow{4}{*}{$\begin{array}{l}\mathrm{B}^{\mathrm{a}}(\alpha \text {-pinene, } \\
\text { 1-butanol })\end{array}$} & B1f & 47 & 28.2 & $2.8 \pm 0.2$ & $1.2 \pm 0.1$ & $1.2 \pm 0.1$ & 6.9 & 0.23 \\
\hline & $\mathrm{B} 1 \mathrm{~b}$ & 47 & 28.2 & $2.9 \pm 0.4$ & $-0.7 \pm 0.2$ & - & 0.4 & 0.21 \\
\hline & B2f & 16.8 & 10.1 & - & - & - & 6.3 & 0.22 \\
\hline & $\mathrm{B} 2 \mathrm{~b}$ & 16.8 & 10.1 & - & - & - & - & - \\
\hline \multirow{4}{*}{$\begin{array}{l}\mathrm{C}(\alpha \text {-pinene, } \\
\text { cyclohexane })\end{array}$} & C1f & 24.5 & 14.7 & $2.4 \pm 0.5$ & $0.5 \pm 0.1$ & $0.6 \pm 0.1$ & 8.9 & 0.23 \\
\hline & $\mathrm{C} 1 \mathrm{~b}$ & 24.5 & 14.7 & - & - & - & 0.9 & 0.22 \\
\hline & $\mathrm{C} 2 \mathrm{f}$ & 26.7 & 16.5 & $1.7 \pm 0.3$ & $1.0 \pm 0.1$ & $0.7 \pm 0.1$ & 11.7 & 0.23 \\
\hline & $\mathrm{C} 2 \mathrm{~b}$ & 26.7 & 16.5 & - & - & $-0.8 \pm 0.3$ & - & - \\
\hline Handling blank & $\mathrm{HB}$ & - & - & $10.0 \pm 0.8$ & $8.9 \pm 0.1$ & - & $0.23^{b}$ & - \\
\hline
\end{tabular}

a CCN data available; see Sect. S2.

${ }^{\mathrm{b}}$ Surface loading in units of micrograms per square centimetre $\left(\mu \mathrm{g} \mathrm{cm}^{-2}\right)$.

Generated aerosol was sampled after an ozone scrubber on doubly stacked quartz-fibre filters $(4.7 \mathrm{~cm}$ diameter, QMA 1851, Whatman) for offline chemical and isotope analysis at $10 \mathrm{Lmin}^{-1}$. Collection times were around 1-2 days in order to provide sufficient amounts of carbon on the filters for isotope analysis; see Table 2. The ozone scrubber had a denuder design and used potassium iodine (Williams and Grosjean, 1990). It protected instruments from high ozone levels but also precluded further reaction of collected samples with ozone on the filters.

Several instruments monitored gaseous and particulate matter inside the bag: a scanning mobility particle sizer (SMPS; TSI 3081 DMA and $3772 \mathrm{CPC}, 0.0508 \mathrm{~cm}$ impactor) was used to measure particle size distributions $(10-500 \mathrm{~nm}$ diameter if not stated otherwise) and a cloud condensation nuclei (CCN) counter (Droplet Measurement Technologies) gave information on the CCN properties of generated SOA (King et al., 2012). Temperature and relative humidity were measured continuously inside the bag (HygroFlex HF532,
Rotronic) and read by the same software that controlled the pressure inside the bag. $\mathrm{NO}_{x}\left(=\mathrm{NO}+\mathrm{NO}_{2}\right)$ levels were monitored using a chemiluminescence $\mathrm{NO}_{x}$ analyzer $(42 i$, Thermo). The same line fed a UV photometric $\mathrm{O}_{3}$ analyzer (49i, Thermo) to monitor ozone levels.

\section{$2.3 \alpha$-pinene ozonolysis}

All aerosol was generated from the dark ozonolysis of $\alpha$ pinene under low- $\mathrm{NO}_{x}$ conditions $(<2 \mathrm{ppb})$ without any seed particles present. Experiments were performed with two different $\mathrm{OH}$ scavengers: Experiment $\mathrm{B}$ with 1-butanol and Experiment $\mathrm{C}$ with cyclohexane. The amount of $\alpha$-pinene injected using the syringe pump resulted in a steady-state concentration of ca. $60 \mathrm{ppb}$ inside the bag (without oxidants). Ozone concentrations during the experiment were always above $150 \mathrm{ppb}$, i.e. ozone was always in excess. The temperature was stable at $22{ }^{\circ} \mathrm{C}$ and $\mathrm{RH}<1 \%$. Without seed particles present, aerosol formed via new particle formation. 
Table 2 gives an overview of the conditions under which experiments $\mathrm{B}$ and $\mathrm{C}$ were performed.

The natural ( $e$-folding) lifetime of $\alpha$-pinene with respect to ozonolysis is $\tau_{\mathrm{O}_{3}}=\left(k\left[\mathrm{O}_{3}\right]\right)^{-1}=40 \mathrm{~min}$, based on an ozone concentration of $150 \mathrm{ppb}$ and a second-order rate coefficient of $k=1.1 \times 10^{-16} \mathrm{~cm}^{3}$ molecule ${ }^{-1} \mathrm{~s}^{-1}$ (Witter et al., 2002). The nominal residence time of an air parcel in the chamber is $\tau_{\text {nominal }} \approx 3.4 \mathrm{~h}$ (see Sect. S1) which exceeds the natural lifetime with respect to ozone loss by a factor of 5 . This means that more than $99 \%$ of $\alpha$-pinene will have reacted at steady state, and for further evaluation and discussion it is assumed that $\alpha$-pinene ozonolysis was complete. As total mass is conserved for all isotopes, the isotopic composition of the ozonolysis products should be equal to that of the initial reagent.

\subsection{Filter handling protocol}

Glass vials with plastic stoppers were used to store the quartz filters for off-line analysis before and after the experiments. The glass vials themselves were cleaned in a ceramic oven at $600^{\circ} \mathrm{C}$ for $24 \mathrm{~h}$ prior to use. The quartz filters were cleaned in the same oven at $600^{\circ} \mathrm{C}$ for more than $20 \mathrm{~h}$ prior to use. Each filter was stored in a separate glass vial that was wrapped in aluminium foil and stored in a dark freezer $\left(-30^{\circ} \mathrm{C}\right)$ except when loading or during transport between Copenhagen and Utrecht. Two quartz filters (quartz behind quartz, QBQ) were loaded at a time in a cleaned filter holder to account for possible sampling artefacts, such as adsorption and evaporation of organic vapours on or from the filters (Watson et al., 2009; Turpin et al., 2000). In this study the first filter, facing the sample stream, is called the front filter, while the second one (stacked below) is called the back filter. Storage time between loading and analysis was up to 6 months. During transport the filters stayed in the wrapped vials but were not actively cooled. Prior to analysis the filters were cut into pieces of uniform size $(0.5$ and $1 \mathrm{~cm}$ diameter). Blank filters were treated identically to loaded filters but were not exposed to chamber air. Gloves were used whenever working directly with the filters, and all tools were rinsed several times using first acetone and then ethanol.

\subsection{Filter analysis}

The filter samples from the smog chamber experiments were analysed for their chemical and isotopic composition at the Institute for Marine and Atmospheric research Utrecht (IMAU). Propagated uncertainties based on at least three measurements are given as 1-sigma errors. Filter IDs (identifications) are composed of a capital letter denoting the experiment (B using 1-butanol or $\mathrm{C}$ using cyclohexane as $\mathrm{OH}$ scavenger), a digit counting the experiments using that scavenger, and a small letter indicating the filter position: $b$ for back filter and $f$ for front filter.

\subsubsection{Thermal-desorption chemical analysis of filters}

The chemical analysis follows methods described earlier (Holzinger et al., 2010b; Timkovsky et al., 2015) and will only be outlined briefly here. The chemical analysis setup consisted of a two-stage oven. Filter pieces were heated stepwise in the first oven to temperatures of $100,150,200$, 250,300 , and $350^{\circ} \mathrm{C}$, while the temperature of the second oven was kept constant at $200^{\circ} \mathrm{C}$. SOA components desorbed from the filters according to their volatility and a flow of nitrogen $\left(50 \mathrm{~mL} \mathrm{~min}^{-1}\right)$ carried them to the PTRMS (PTR-TOF8000, Ionicon Analytik GmbH, Austria) situated directly after the second oven. The PTR-MS inlet was heated to its maximum temperature of $180^{\circ} \mathrm{C}$, while the drift tube was operated at $120^{\circ} \mathrm{C}$. This monotonic gradient from the first oven stage to the drift tube inside the PTR-MS reduced cold spots and minimised repeated sample condensation. The PTR-MS detected the desorbed compounds after protonation (addition of ${ }^{1} \mathrm{H}$ ) as ions with a mass-to-charge ratio $(m / z)+1$.

The PTR-MS had a mass resolution of $m / \Delta m \approx 4000$, allowing detection of ions with differences in $m / z$ larger than $30 \mathrm{mDa}$. The algorithm for analysing the PTR-MS data is based on a method reported earlier (Holzinger et al., 2010a; Holzinger, 2015). For each experiment (B or C), the ions detected on the front and back filters were combined in a unified-peak list to minimise statistical uncertainty and improve overall mass accuracy (Holzinger et al., 2010a). Ions with $\mathrm{m} / z<39 \mathrm{Da}$ were excluded (except $33.03 \mathrm{Da}$, methanol, and $31.01 \mathrm{Da}$, formaldehyde) as the PTR-MS mainly detects primary ions in this mass region, which do not originate from the filters. Water clusters with masses 37.026 and $55.038 \mathrm{Da}$ can form in the PTR-MS and were not considered to be aerosol compounds. A total of 685 (753) ions were detected by the PTR-MS in experiment B (C). In order to take the contribution from the blank filter (filter ID "HB" for handling blank) into account, the blank filter loading was calculated from the PTR-MS signal and subtracted from the front and back filters for each ion on the unified-peak list. All concentrations are then reported relative to smog chamber conditions, i.e. as mass concentration per unit volume of air in the smog chamber. Table 2 lists the blank-corrected total mass concentration, $M_{\text {total }}^{\text {PTR }}$. Many ions had negligible concentrations. The 427 (451) ions from the unified-peak list of experiment B (C), comprising $90 \%$ of the total aerosol mass detected by PTR-MS (counting from the ion with highest concentration downwards), were considered for further analysis in order to streamline data analysis and reduce noise.

The data analysis algorithm identified the molecular formulas of the detected ions (i.e. the total number of most abundant stable $\mathrm{C}, \mathrm{H}, \mathrm{O}$, and $\mathrm{N}$ isotopes) based on their exact masses. If the peak resolution did not allow unambiguous identification, several candidates were suggested (Holzinger et al., 2010a). The suggested formulas for all prominent peaks were checked manually on at least two filters and cor- 
rected if necessary, including when the suggested formula contained $\mathrm{N}$ or ${ }^{13} \mathrm{C}$. The former can be excluded due to the low- $\mathrm{NO}_{x}$ conditions in the experiment, and the latter can be easily verified by the corresponding carbon-12 peak at $(m / z-1)+1$. Most of the ions were identified unambiguously and typically only ca. $5 \%$ of the total mass from front filter desorption was attributed to ions with no clear molecular formula.

The oxygen-to-carbon ratios of the ions were calculated as in (Holzinger et al., 2013) for each filter at each desorption temperature:

$\mathrm{O}: \mathrm{C}=\frac{\sum w_{i} n_{\mathrm{O}, i}}{\sum w_{i} n_{\mathrm{C}, i}}$.

Here, the sum counts over all identified ions $i, w_{i}$ is the measured amount of ion $i$ in moles (mol) and $n_{\mathrm{C}, i}$, and $n_{\mathrm{O}, i}$ are the respective number of carbon and oxygen atoms for ion $i$ as given by its molecular formula. Equation (1) gives the ratio of oxygen to carbon atoms in all identified ions.

\subsubsection{Thermal-desorption isotope analysis of filters}

The system used to measure the carbon isotope composition of the filter samples consisted of a two-stage oven, as described in detail by (Dusek et al., 2013). The filter pieces were heated stepwise in the first oven stage to temperatures of $100,150,200,250,300,340$, and $390^{\circ} \mathrm{C}$, desorbing SOA compounds according to their volatility. In the second oven stage, the gaseous compounds were oxidised to $\mathrm{CO}_{2}$ at $550^{\circ} \mathrm{C}$ using a platinum wool catalyst. The $\mathrm{CO}_{2}$ was dried and purified using two cold traps and a gas chromatography column before it was analysed in a Delta Plus XL isotope ratio mass spectrometer (IR-MS; Thermo). The catalyst was charged using pure $\mathrm{O}_{2}$ and then a filter piece was placed in the oven which was subsequently flushed with helium. The heating of the filter and subsequent purification of $\mathrm{CO}_{2}$ took place in a helium carrier gas flow. Filter samples were bracketed between blank filter samples. IR-MS detects each isotopologue of $\mathrm{CO}_{2}$ as a distinct peak with an associated peak area. The $\delta\left({ }^{13} \mathrm{C}\right)$ value was calculated from these areas (see below). Reported data were corrected by taking the corresponding blank filter measurements into account.

Isotope data are commonly reported in delta notation, using Vienna Pee Dee Belemnite (VPDB), as an elementspecific international standard for ${ }^{13} \mathrm{C}$ :

$\delta\left({ }^{13} \mathrm{C}\right)=\frac{R_{\mathrm{Sa}}\left({ }^{13} \mathrm{C}\right)}{R_{\mathrm{VPDB}}\left({ }^{13} \mathrm{C}\right)}-1$.

Here, $R_{\mathrm{Sa}}\left({ }^{13} \mathrm{C}\right)$ and $R_{\mathrm{VPDB}}\left({ }^{13} \mathrm{C}\right)$ denote the isotope ratios $\left({ }^{13} \mathrm{C} /{ }^{12} \mathrm{C}\right)$ in the sample and standard, respectively. For typical ambient samples, the reproducibility lies below $0.3 \%$ for oven temperatures below $200^{\circ} \mathrm{C}$ and below $0.5 \%$ o for oven temperatures above $200^{\circ} \mathrm{C}$ (Dusek et al., 2013).
In this study isotopic compositions of filter material are discussed relative to the isotopic composition of the initial $\alpha$-pinene, $\delta_{\mathrm{TC}}^{\circ 1}\left({ }^{13} \mathrm{C}\right)$, where TC denotes total carbon analysis (see below). Changes in isotopic composition are then reported as an isotopic difference (Coplen, 2011):

$\Delta\left({ }^{13} \mathrm{C}\right)=\delta\left({ }^{13} \mathrm{C}\right)-\delta_{\mathrm{TC}}^{\circ 1}\left({ }^{13} \mathrm{C}\right)$,

where $\Delta\left({ }^{13} \mathrm{C}\right)>0$ indicates enrichment and $\Delta\left({ }^{13} \mathrm{C}\right)<0$ indicates depletion in ${ }^{13} \mathrm{C}$ with respect to the initial $\alpha$-pinene.

\subsection{Total carbon isotope analysis of $\alpha$-pinene and selected filters}

The $\alpha$-pinene used in the smog chamber experiments and selected filters (see Table 2) were transferred into tin capsules $(4 \times 6 \mathrm{~mm}$ capsules from Lüdi AG, Flawil, Switzerland), weighed, and analysed for total carbon isotopic composition, $\delta_{\mathrm{TC}}\left({ }^{13} \mathrm{C}\right)$ in the ISOLAB of the Max Planck Institute for Biogeochemistry in Jena, Germany. The analytical setup comprised an elemental analyser (EA-1100, Carlo Erba, Milan, Italy) which was coupled to a Delta+ IR-MS (Finnigan MAT, Bremen, Germany) through a ConFlo III interface (Werner et al., 1999). The complete system was described by Brooks et al. (2003). All $\delta_{\mathrm{TC}}\left({ }^{13} \mathrm{C}\right)$ isotope ratios were referenced against the VPDB scale using an in-house working standard which itself is referenced against NBS-22 (National Bureau of Standards, now NIST), with a prescribed value of $-30.03 \%$ (Coplen et al., 2006). Blank tests within each measurement sequence were used for blank correction. The analytical performance was maintained and monitored according to a measurement protocol that was described by Werner and Brand (2001). The estimated uncertainty of the $\delta_{\mathrm{TC}}\left({ }^{13} \mathrm{C}\right)$ analysis was $0.11 \%$, based on long-term performance records. The total carbon isotopic composition is reported here as $\delta_{\mathrm{TC}}^{\circ 1}\left({ }^{13} \mathrm{C}\right)$ for the initial $\alpha$-pinene used in the smog chamber experiments and as isotopic difference with subscript $\mathrm{TC}, \Delta_{\mathrm{TC}}\left({ }^{13} \mathrm{C}\right)=\delta_{\mathrm{TC}}\left({ }^{13} \mathrm{C}\right)-\delta_{\mathrm{TC}}^{\circ 1}\left({ }^{13} \mathrm{C}\right)$, for all other samples.

\subsection{Position-specific isotope analysis of $\alpha$-pinene}

Quantitative NMR spectrometry tuned for isotopic measurements was used to quantify the relative abundance of each carbon isotopomer of $\alpha$-pinene. The sample preparation for NMR analysis consisted of the successive addition of $100 \mu \mathrm{L}$ of a relaxing agent, $\mathrm{Cr}(\mathrm{Acac})_{3}$ (Merck) at $0.1 \mathrm{M}$ in the lock substance, Acetone- $\mathrm{d}_{6}$ (EURISOTOP), to a $4 \mathrm{~mL}$ vial. Then $600 \mu \mathrm{L}$ of pure $\alpha$-pinene was added and the mixture was introduced into a $5 \mathrm{~mm}$ NMR tube. Quantitative ${ }^{13} \mathrm{C}$ NMR spectra were recorded using a Bruker AVANCE III connected to a $5 \mathrm{~mm}$ internal diameter BBFO probe tuned to the recording frequency of $100.62 \mathrm{MHz}$. The temperature of the probe was set to $303 \mathrm{~K}$, without tube rotation. The acquisition conditions were those recommended in previous works 
(Bayle et al., 2014b; Silvestre et al., 2009) and are detailed in Sect. S5. Isotope ${ }^{13} \mathrm{C} /{ }^{12} \mathrm{C}$ ratios were calculated from processed spectra (see Fig. S4) as described previously (Bayle et al., 2014b; Silvestre et al., 2009); see Sect. S5. The measured position-specific isotopic compositions are given in delta notation and denoted as $\delta_{i}\left({ }^{13} \mathrm{C}\right)$ where $i$ denotes the position of the $\mathrm{C}$ atom; see Fig. 7. Typical accuracy of $\delta_{i}\left({ }^{13} \mathrm{C}\right)$ is $1 \%$.

Total carbon isotopic abundance, $\delta_{\mathrm{TC}}^{\circ j}\left({ }^{13} \mathrm{C}\right)$, was determined by IR-MS using an Integra2 spectrometer (Sercon Instruments, Crewe, UK) linked to a Sercon elemental analyser. Here, $j$ denotes different $\alpha$-pinene samples as listed in Table 1 (PSIA was only performed for samples $j=2 \ldots .5$ ). A precision balance (Ohaus Discovery DV215CD) has been used to introduce $0.5 \mathrm{mg}$ of pure $\alpha$ pinene into tin capsules $(2 \times 5 \mathrm{~mm}$, Thermo Fisher scientific), before loading them into the elemental analyser. The instrument was referenced against the VPDB scale using international reference materials NBS-22 $\left(\delta_{\mathrm{VPDB}}\left({ }^{13} \mathrm{C}\right)=\right.$ $-30.03 \%$ ) , SUCROSE-C6 $\left(\delta_{\mathrm{VPDB}}\left({ }^{13} \mathrm{C}\right)=-10.80 \%\right)$, and IAEA-CH-7 PEF-1 $\left(\delta_{\text {VPDB }}\left({ }^{13} \mathrm{C}\right)=-32.15 \%\right.$ ) (IAEA, Vienna, Austria). Instrumental deviation was followed via a laboratory standard of glutamic acid. The corresponding position-specific isotopic difference is reported as $\Delta_{i}\left({ }^{13} \mathrm{C}\right)=$ $\delta_{i}\left({ }^{13} \mathrm{C}\right)-\delta^{\circ j}\left({ }^{13} \mathrm{C}\right)$.

\section{Results}

\subsection{Aerosol characteristics}

The evolution of SMPS-derived size distributions and total mass concentrations over time show that the aerosol population inside the bag was nearly constant for several days after the first day; see Fig. S2 and panel (a) in Fig. S3. Sampling on filters was started ca. $24 \mathrm{~h}$ after the injection of VOCs into the chamber. The CCN activity of SOA generated in this study resembles literature data for $\alpha$-pinene SOA generated in batch mode chambers (Fig. S3b). The integrated SMPS size distribution provides an estimate of the total SOA mass concentration in the chamber: 22 and $25 \mu \mathrm{g} \mathrm{m}^{-3}$ for experiment $\mathrm{B}$ and $\mathrm{C}$, respectively, although particles larger than $500 \mathrm{~nm}$ are not accounted for. A detailed characterisation of the chamber aerosol can be found in Sect. S2.

\subsection{Chemical composition}

\subsubsection{Blank filter}

Very low surface loadings $\left(0.23 \mu \mathrm{g} \mathrm{cm}^{-2}\right)$ were found on the blank filter (HB); see Table 2. No peaks above $220 \mathrm{Da}$ were detected. $\mathrm{C}_{3} \mathrm{H}_{6} \mathrm{OH}^{+}$(corresponding to protonated acetone) was the only compound found on the blank filter in concentrations above $5 \mathrm{ng} \mathrm{cm}^{-2}$ at $100^{\circ} \mathrm{C}$, while all other ions showed temperature-independent concentrations below that.

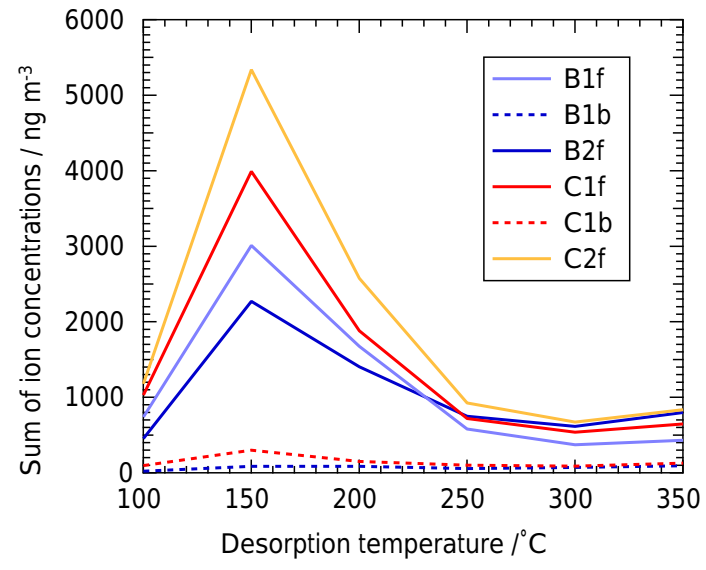

Figure 2. Sum of mass concentrations of desorbed SOA filter material from $\alpha$-pinene ozonolysis, as detected by PTR-MS. The concentrations of all detected ions were summed for each desorption temperature. Full lines represent front filters, dashed lines back filters.

High concentrations of acetone desorbed from all filters at $100^{\circ} \mathrm{C}$ and may be an artefact from cleaning, although acetone is produced in the reaction, as shown in Fig. 1. The total surface loadings of the front and back filters always exceeded those on the blank filter except for single ions with concentrations near the detection limit, sometimes found desorbing from back filters at temperatures other than $150{ }^{\circ} \mathrm{C}$. Correction for the blank filter concentration then resulted in negative concentrations for these ions for the back filters. These cases were neglected in the further data analysis.

\subsubsection{Concentration thermograms}

Figure 2 shows the sum of mass concentrations at each temperature step, as measured by PTR-MS. All front filters (B1f, B2f, C1f, and C2f) show a similar profile with most of the mass desorbing at $150^{\circ} \mathrm{C}$. The back filters (B1b and $\mathrm{C} 1 \mathrm{~b})$ are used to characterise the positive sampling artifact, namely gas-phase compounds that adsorb to the quartz-fibre filters. Material collected on QBQ back filters can be assumed to mainly consist of adsorbed gas-phase compounds corresponding to a positive gas-phase artefact (Cheng and $\mathrm{He}, 2015)$. This is confirmed by the chemical analysis of back filters in this study, which differs considerably from that of the corresponding front filters, as detailed in Sect. S3. The back filters show small mass loadings - roughly 6 and $13 \%$ of the masses of their respective front filters. The large mass difference between front and back filters suggests efficient sampling of a dominant aerosol phase on front filters and a small positive sampling artifact. The front filters were not corrected for the sampling artifact.

The total SOA mass concentration in the chamber derived from PTR-MS measurements was of the order of $10 \mu \mathrm{g} \mathrm{m}^{-3}$; see Table 2. Overall, the SMPS measured total mass concen- 

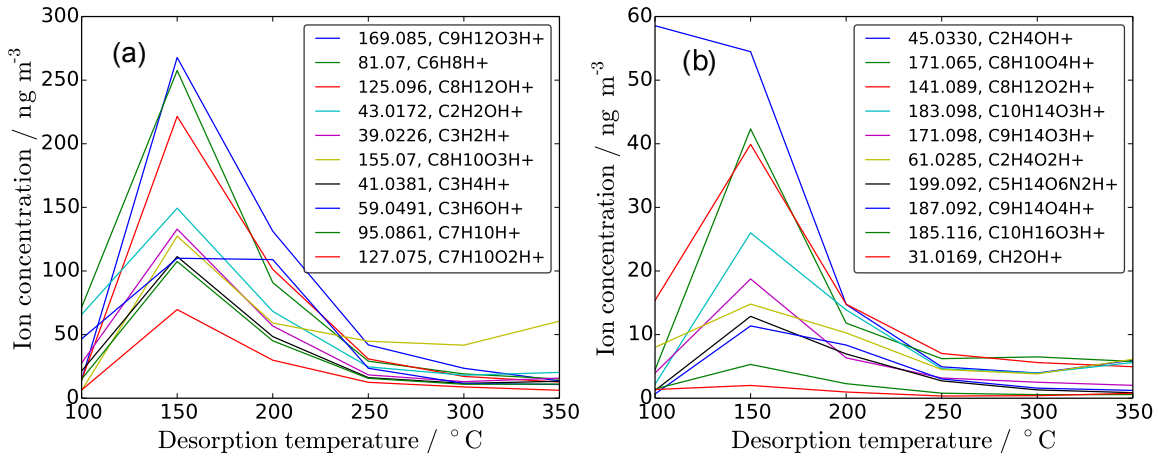

Figure 3. Mass concentration thermograms of compounds desorbing from filter C1f as detected by PTR-MS. Filter C1f contains SOA from $\alpha$-pinene ozonolysis in dark and dry conditions using cyclohexane as an $\mathrm{OH}$ scavenger. All ions are labelled by their masses in daltons (Da) and their identified molecular formula. Ions with the largest concentrations are listed first. The 10 ions with highest mass concentrations are plotted in (a). The most abundant ions found in this study with masses similar to compounds reported in the literature (see Table 3) are plotted in (b). These are the same compounds as those below the line in Table 4 and include those predicted by the MCM, e.g. pinic acid $(187.093 \mathrm{Da})$ and pinonic acid $(185.117 \mathrm{Da})$. See Sect. S4 for more details. Most ions show a peak at $150{ }^{\circ} \mathrm{C}$, but their desorption patterns differ at lower and higher temperatures.

Table 3. Main references cited in this study for comparison of chemical composition. The identifier (last column) denotes the letter the reference corresponds to in Table 4 and Sect. S6. Abbreviations: QP: quadrupole; TD: thermal desorption; TOF: time-of-flight; LC: liquid chromatography; MS: mass spectrometer; GC: gas chromatography; HP: high performance.

\begin{tabular}{lllll}
\hline Study & Sample & Sample phase & Instrumentation / method & Identifier \\
\hline (Holzinger et al., 2005) & Ambient, forest & Gas & PTR-MS (QP) & - \\
(Holzinger et al., 2010a) & Ambient, Austrian Alps & Aerosol & TD-PTR-MS (TOF) & a \\
(Winterhalter et al., 2003) & $\alpha$-pinene ozonolysis & Aerosol & LC-MS & $\mathrm{b}$ \\
(Jaoui and Kamens, 2003) & $\alpha$-pinene $+\beta$-pinene ozonolysis & Aerosol & GC-MS, HP-LC & $\mathrm{c}$ \\
(Jenkin, 2004) & $\alpha$-pinene ozonolysis & Gas + aerosol & Modelling & $\mathrm{d}$ \\
(Camredon et al., 2010) & $\alpha$-pinene ozonolysis & Gas + aerosol & MCM Modelling & $*$ \\
\hline
\end{tabular}

* MCM names.

trations that were up to 4 times higher than the concentrations measured by PTR-MS. This difference might be due to some factors related to the individual steps of the chemical analysis, e.g. filter sampling, extraction from the filter, and analysis by PTR-MS. An earlier study using an impactorbased thermal-desorption PTR-MS concluded that the total aerosol mass measured was typically $20 \%$ lower than the total aerosol mass measured with an SMPS (Holzinger et al., 2010b). The authors estimated conservatively that their PTRMS setup detected $55-80 \%$ of the total aerosol mass. Filter sampling losses of up to $10 \%$ were attributed to negative sampling artefacts, i.e. evaporation from the filter, during sampling times of $24 \mathrm{~h}$ or longer in earlier work (Subramanian et al., 2004). The maximum desorption temperature during chemical analysis was only $350^{\circ} \mathrm{C}$, and previous studies on $\beta$-pinene ozonolysis and photo-oxidation of terpenes also showed significant remaining volume fractions at desorption temperatures exceeding $400^{\circ} \mathrm{C}$ (Emanuelsson et al., 2013, 2014). Finally, charring and fragmentation in the PTR-MS can additionally lower PTR-MS-derived total mass concentrations. Section $\mathrm{S} 4$ describes these processes in more detail, as well as other aspects relevant to PTR-MS data interpretation.

Figure 3 shows mass concentration thermograms of specific compounds desorbing from front filter C1f. Table 4 complements information in Fig. 3, and Sect. S6 gives the full list of ions detected by PTR-MS from filter C1f. In Fig. 3 most ions show the highest concentrations at a desorption temperature of $150^{\circ} \mathrm{C}$, in agreement with Fig. 2 .

A pure compound is expected to desorb from the filter at temperatures between its melting and boiling temperatures. (Dusek et al., 2013) observed this on the same analytical setup for dicarboxylic acids. In principle, pure compounds will be detected by the PTR-MS as an ion of similar mass and only in this temperature window. There are several possible reasons why the same ion is observed over a range of temperatures. Since fragmentation of chemical compounds can occur during thermal desorption in the oven and ionisation in the PTR-MS (see Sect. S4), a fraction of the detected ions are likely fragments of larger (heavier) compounds. This fragmentation can occur at all desorption temperatures and consequently fragments are detected over a range of temper- 
Table 4. The 20 ions with the highest concentrations from filter $\mathrm{C} 1 \mathrm{f}$ at $150^{\circ} \mathrm{C}$, plus 10 ions with nominal masses similar to protonated compounds commonly reported in the literature (below the line). Ions are sorted by their measured mass $(\mathrm{m} / \mathrm{z}$ ). The chemical formula and concentration, $w$, are shown for each ion, and in parenthesis, its ranking out of the 451 ions. The concentration ratio between back filter $\mathrm{C} 1 \mathrm{~b}$ and the corresponding front filter (C1f) at $150^{\circ} \mathrm{C}$ is calculated for each listed compound. Assignments in the literature which seem to be in error are indicated by parenthesis. Ions that are part of the same sequence of the $\mathrm{H}_{2} \mathrm{O}$-loss fragmentation pattern (see Sect. S4 for definition) are numbered relative to each other as $\pm n \times 18.011 \mathrm{Da}$ ( $\pm n$ and the compound's ranking are given). Here a dash means that the peak was identified but not resolved. The list of all ions detected from compounds desorbing from filter 6 can be found in Sect. S6.

\begin{tabular}{|c|c|c|c|c|c|c|}
\hline Mass (Da) & Formula & $w\left(\mathrm{ng} \mathrm{m}^{-3}\right.$, rank $)$ & Back/Front & Description & Literature & $\mathrm{H}_{2} \mathrm{O}$ number $n$ (rank) \\
\hline 39.0226 & $\left(\mathrm{C}_{3} \mathrm{H}_{2}\right) \mathrm{H}^{+}$ & $132.93(5)$ & 0.03 & & & \\
\hline 41.0381 & $\left(\mathrm{C}_{3} \mathrm{H}_{4}\right) \mathrm{H}^{+}$ & $111.32(7)$ & 0.03 & & & \\
\hline 43.0172 & $\left(\mathrm{C}_{2} \mathrm{H}_{2} \mathrm{O}\right) \mathrm{H}^{+}$ & 149.37 (4) & 0.05 & & $\mathrm{a}$ & \\
\hline 45.033 & $\left(\mathrm{C}_{2} \mathrm{H}_{4} \mathrm{O}\right) \mathrm{H}^{+}$ & $54.47(16)$ & 0.01 & Acetaldehyde & $\mathrm{a}$ & $+1(336)$ \\
\hline 59.0491 & $\left(\mathrm{C}_{3} \mathrm{H}_{6} \mathrm{O}\right) \mathrm{H}^{+}$ & $110.01(8)$ & 0.06 & Acetone & $\mathrm{a}, \mathrm{c}$ & \\
\hline 67.0546 & $\left(\mathrm{C}_{5} \mathrm{H}_{6}\right) \mathrm{H}^{+}$ & $50.57(18)$ & 0.04 & & & \\
\hline 69.0337 & $\left(\mathrm{C}_{4} \mathrm{H}_{4} \mathrm{O}\right) \mathrm{H}^{+}$ & $49.81(19)$ & 0.01 & & & \\
\hline 69.0699 & $\left(\mathrm{C}_{5} \mathrm{H}_{8}\right) \mathrm{H}^{+}$ & $43.60(20)$ & 0.03 & & & \\
\hline 81.07 & $\left(\mathrm{C}_{6} \mathrm{H}_{8}\right) \mathrm{H}^{+}$ & $257.57(2)$ & 0.03 & Similar to no. 9 & & $+1(32)$ \\
\hline 83.0496 & $\left(\mathrm{C}_{5} \mathrm{H}_{6} \mathrm{O}\right) \mathrm{H}^{+}$ & $66.57(11)$ & 0.05 & & $\mathrm{a}$ & $+1(62),-1(96)$ \\
\hline 85.065 & $\left(\mathrm{C}_{5} \mathrm{H}_{8} \mathrm{O}\right) \mathrm{H}^{+}$ & $56.71(14)$ & 0.01 & & & \\
\hline 95.0861 & $\left(\mathrm{C}_{7} \mathrm{H}_{10}\right) \mathrm{H}^{+}$ & $107.50(9)$ & 0.03 & Similar to no. 2 & & \\
\hline 107.086 & $\left(\mathrm{C}_{8} \mathrm{H}_{10}\right) \mathrm{H}^{+}$ & $64.79(12)$ & 0.19 & & & \\
\hline 123.081 & $\left(\mathrm{C}_{8} \mathrm{H}_{10} \mathrm{O}\right) \mathrm{H}^{+}$ & $53.69(17)$ & 0.02 & & $\mathrm{a}$ & $-1(58)$ \\
\hline 125.096 & $\left(\mathrm{C}_{8} \mathrm{H}_{12} \mathrm{O}\right) \mathrm{H}^{+}$ & $221.48(3)$ & 0.02 & & & \\
\hline 127.075 & $\left(\mathrm{C}_{7} \mathrm{H}_{10} \mathrm{O}_{2}\right) \mathrm{H}^{+}$ & $69.69(10)$ & 0.01 & & & \\
\hline 141.054 & $\left(\mathrm{C}_{7} \mathrm{H}_{8} \mathrm{O}_{3}\right) \mathrm{H}^{+}$ & $56.22(15)$ & 0.17 & & $\mathrm{a}$ & $+1(63)$ \\
\hline 155.07 & $\left(\mathrm{C}_{8} \mathrm{H}_{10} \mathrm{O}_{3}\right) \mathrm{H}^{+}$ & $127.41(6)$ & 0.01 & & $\mathrm{a},(\mathrm{b}, \mathrm{d})$ & $+1(13)$ \\
\hline 169.085 & $\left(\mathrm{C}_{9} \mathrm{H}_{12} \mathrm{O}_{3}\right) \mathrm{H}^{+}$ & $267.79(1)$ & 0.01 & & $(c, d), a$ & $+1(72),-1(22),-2(202)$ \\
\hline 173.079 & $\left(\mathrm{C}_{8} \mathrm{H}_{12} \mathrm{O}_{4}\right) \mathrm{H}^{+}$ & $58.75(13)$ & 0.01 & Norpinonic acid & $\mathrm{b}, \mathrm{d},(\mathrm{b})$ & $-1(6)$ \\
\hline 31.017 & $\left(\mathrm{CH}_{2} \mathrm{O}\right) \mathrm{H}^{+}$ & $2.01(179)$ & 0.07 & Formaldehyde & $\mathrm{a}, \mathrm{c}, \mathrm{d}$ & \\
\hline 61.0286 & $\left(\mathrm{C}_{2} \mathrm{H}_{4} \mathrm{O}_{2}\right) \mathrm{H}^{+}$ & $14.80(59)$ & 0.06 & Acetic acid & $\mathrm{a}$ & \\
\hline 141.089 & $\left(\mathrm{C}_{8} \mathrm{H}_{12} \mathrm{O}_{2}\right) \mathrm{H}^{+}$ & $39.91(24)$ & 0.03 & 2,2-Dimethyl-cyclobutyl-1,3-diethanal & $a, d,(d)$ & \\
\hline 171.065 & $\left(\mathrm{C}_{8} \mathrm{H}_{10} \mathrm{O}_{4}\right) \mathrm{H}^{+}$ & $42.34(21)$ & 0.03 & Not norpinonic acid & $\mathrm{a},(\mathrm{b}, \mathrm{c}, \mathrm{d})$ & $-1(-)$ \\
\hline 171.098 & $\left(\mathrm{C}_{9} \mathrm{H}_{14} \mathrm{O}_{3}\right) \mathrm{H}^{+}$ & $18.75(48)$ & 0.07 & Norpinonic acid (?) & $\mathrm{b}, \mathrm{c}, \mathrm{d}$ & \\
\hline 183.099 & $\left(\mathrm{C}_{10} \mathrm{H}_{14} \mathrm{O}_{3}\right) \mathrm{H}^{+}$ & $26.00(35)$ & 0.03 & C109CO, 4-Oxopinonaldehyde & $\mathrm{b}, \mathrm{c}, \mathrm{d}$ & $+1(232),+2(-)$ \\
\hline 185.117 & $\left(\mathrm{C}_{10} \mathrm{H}_{16} \mathrm{O}_{3}\right) \mathrm{H}^{+}$ & $5.31(114)$ & 0.12 & $\begin{array}{l}\text { Pinonic acid, OH-pinonaldehyde, } \\
\text { PINONIC, C107OH, C109OH }\end{array}$ & (a), b, c, d & $-1(51),-2(132)$ \\
\hline 187.093 & $\left(\mathrm{C}_{9} \mathrm{H}_{14} \mathrm{O}_{4}\right) \mathrm{H}^{+}$ & $11.37(71)$ & 0.01 & Pinic acid, $10-\mathrm{OH}$ norpinonic acid, PINIC & $\mathrm{b},(\mathrm{b},) \mathrm{c}, \mathrm{d}$ & $-1(1),-2(22),-3(200)$ \\
\hline 199.093 & $\left(\mathrm{C}_{10} \mathrm{H}_{14} \mathrm{O}_{4}\right) \mathrm{H}^{+}$ & $12.87(66)$ & 0.01 & Oxopinonic acid, keto-pinonic acid & $\mathrm{b}, \mathrm{d}$ & $-1(27),-2(105),+1(380)$ \\
\hline
\end{tabular}

a (Holzinger et al., 2010a). ${ }^{\mathrm{b}}$ (Winterhalter et al., 2003). ${ }^{\mathrm{c}}$ (Jenkin, 2004). ${ }^{\mathrm{d}}$ (Jaoui and Kamens, 2003).

atures. The detection of small ions that are not likely to be present in the particle phase by themselves, over a wide range of desorption temperatures, indicates oligomers. Moreover, an SOA particle usually does not consist of a single compound, but is rather a complex mixture of compounds (Cappa et al., 2008). A specific compound in this mixture will only desorb significantly, when the melting point of the mixture is reached, which might differ from the melting point of the single compound. Recent studies show that high molecular weight dimer esters contribute significantly to SOA from the ozonolysis of $\alpha$-pinene (Kristensen et al., 2016). These low volatile compounds are believed to form from gas-phase reactions of the $\alpha$-pinene-derived Criegee intermediate with abundant $\alpha$-pinene oxidation products such as pinic acid. Recent work by (Lopez-Hilfiker et al., 2016) and (IsaacmanVanWertz et al., 2016) have presented important examples of simultaneous chemical characterisation of organic molecules in both the particle and gas phases, in order to better under- stand partitioning. Decomposition of the dimer esters, such as those reported in Kristensen et al. (2016), and subsequent volatilisation of the carboxylic acid moieties could at least partly explain the detection of specific ions over a range of desorption temperatures.

The relative contributions of different compounds to the total SOA mass was similar on front filters, despite differences in total concentrations. For instance, the top 10 ions (ranked by amount) desorbing from filter $\mathrm{C} 1 \mathrm{f}$ at $150^{\circ} \mathrm{C}$ (panel (a) in Fig. 3 and Table 2) can be found in nearly the same order on filters B1f, B2f, and C2f (not shown). However, filters $\mathrm{C} 1 \mathrm{f}$ and $\mathrm{C} 2 \mathrm{f}$ show higher concentrations compared to filters B1f and B2f; see also Table 2. Different aerosol yields were reported earlier when using different $\mathrm{OH}$ scavengers in carbohydrate ozonolysis experiments (Docherty and Ziemann, 2003; Keywood et al., 2004). The reaction of $\mathrm{OH}$ with different scavengers generates different products. Consequently, the $\mathrm{RO}_{2} / \mathrm{HO}_{2}$ ratios change de- 
pending on the scavenger used, influencing the volatility distribution of products of $\alpha$-pinene SOA. Overall, an increase of SOA yield is predicted when using cyclohexane as $\mathrm{OH}$ scavenger compared to 2-butanol (Jenkin, 2004). Assuming that 1-butanol behaves like 2-butanol (Shilling et al., 2008), the larger desorbed aerosol mass detected by PTR-MS in the cyclohexane experiments is consistent with these considerations. However, the most abundant reaction products were not affected.

The chemical composition of aerosol found in this study was compared to previously published chemical compositions of ambient aerosol and SOA derived from $\alpha$-pinene ozonolysis (in dry, dark, and low- $\mathrm{NO}_{x}$ conditions). Figure $3 \mathrm{~b}$ shows concentration thermograms of ions with masses attributed to compounds reported previously; see Table 4 . The PTR-MS allowed discrimination of particulate reaction products reported earlier (Holzinger et al., 2005, 2010a; Winterhalter et al., 2003; Jenkin, 2004; Jaoui and Kamens, 2003). In many cases the identification could be positively confirmed, but in some cases an original attribution could be falsified (details can be found in Sect. S4). Some references in Table 4 and in Sect. S5 are bracketed to indicate when the assigned formulae for ion masses differed from those in the literature. Compounds predicted by modelling studies are noted by their capitalised Master Chemical Mechanism name in the description field in Table 4 and Sect. S6, confirming the presence of several predicted species. These compounds include pinic acid (compound no. 72 in Sect. S6) and pinonic acid (no. 116 in Sect. S6) which are also shown in Fig. 1.

Figure 4 shows the mass spectra of compounds that desorbed from filter $\mathrm{C} 1 \mathrm{f}$ at $150^{\circ} \mathrm{C}$. Most ions have a mass below $250 \mathrm{Da}$, indicating no direct observation of oligomers. However, several fragmentation patterns were detected in the data, as highlighted by the arrows in Fig. 4: the light green arrow connects peaks with a mass difference of $14.016 \mathrm{Da}$ (corresponding to a $\mathrm{CH}_{2}$ group), and the dark blue arrow connects peaks with a mass difference of $18.011 \mathrm{Da}$ (water). Details on fragmentation patterns can be found in Sect. S4. Fragmentation patterns in the mass spectra indicate that large compounds like oligomers and/or complex organic mixtures were present on the filters, as also reported in the literature (Docherty et al., 2005; Gao et al., 2004; Cappa et al., 2008; Kristensen et al., 2016), but that these compounds decompose during desorption or in the PTR-MS during ionisation before they can be detected as smaller ions. While the arrows in Fig. 4 indicate the possibility that the peaks, separated by a water or $\mathrm{CH}_{2}$ mass, are from the same molecule, this constitutes only circumstantial evidence and not proof.

\subsubsection{O : C ratio}

Figure 5 shows the measured $\mathrm{O}: \mathrm{C}$ ratio versus desorption temperature for selected filters. The $\mathrm{O}: \mathrm{C}$ ratio of desorbed material increases from 0.18 to 0.25 when the desorption temperature increases from 150 to $250^{\circ} \mathrm{C}$. At higher desorp-

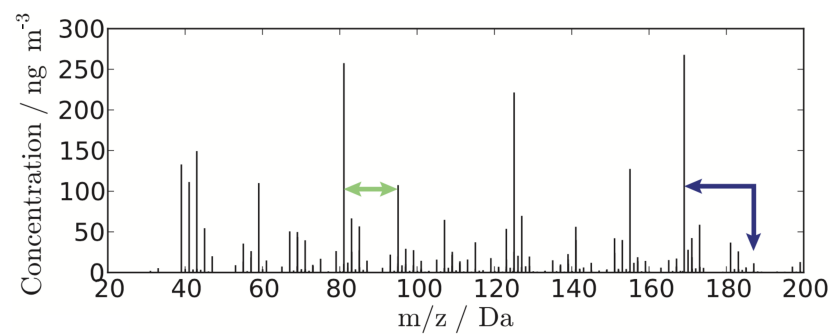

Figure 4. Mass spectrum of SOA from the dark ozonolysis of $\alpha$ pinene (using cyclohexane as $\mathrm{OH}$ scavenger) desorbed from filter $\mathrm{C} 1 \mathrm{f}$ at $150^{\circ} \mathrm{C}$. The presence of lobes with specific periodicity is apparent. The arrows highlight two detected fragmentation patterns that cause the periodicity: that of a $\mathrm{CH}_{2}$ group (light green arrow) and that of water (dark blue arrow); see Sect. S4.

tion temperatures the $\mathrm{O}: \mathrm{C}$ ratio levels off and remains constant at ca. 0.25 . The $\mathrm{O}: \mathrm{C}$ ratios of material desorbing from the back filters are similar to those of the front filters with averages of 0.21 (B1b) and $0.22(\mathrm{C} 1 \mathrm{~b})$; see Table 2.

The observed increase in the $\mathrm{O}: \mathrm{C}$ ratio at increasing desorption temperatures (below $250^{\circ} \mathrm{C}$ ) is to be expected if functionalisation yields oxygenated compounds with lowered volatility (Jimenez et al., 2009; Holzinger et al., 2010b). For material desorbing at temperatures above $250^{\circ} \mathrm{C}$, this correlation seems to break down and oligomerisation is likely to be more important. Oligomerisation reactions can be accompanied by the exclusion of water (Tolocka et al., 2004) that goes undetected in the PTR-MS, lowering O:C ratios. The desorption temperature of formed oligomers and complex mixtures is also higher than the desorption temperature of their single constituents (Cappa et al., 2008). Therefore oligomerisation can decrease the volatility of compounds without raising the $\mathrm{O}: \mathrm{C}$ ratios, resulting in the observed plateau of $\mathrm{O}: \mathrm{C}$ ratios at high desorption temperatures.

Literature values for $\mathrm{O}: \mathrm{C}$ ratios of SOA from $\alpha$-pinene ozonolysis are generally somewhat higher than the values reported here: Shilling et al. (2008) investigated SOA from $\alpha$ pinene ozonolysis and reported $\mathrm{O}: \mathrm{C}$ ratios around 0.33 for aerosol loadings, which are comparable to this study. Aiken et al. (2008) report O : C ratios around 0.3 for laboratory SOA from $\alpha$-pinene ozonolysis and observe more oxidised aerosol in ambient samples. These two studies (Shilling et al., 2008; Aiken et al., 2008) used aerosol mass spectrometers to determine the $\mathrm{O}: \mathrm{C}$ ratio, while Holzinger et al. (2010a) employed a PTR-MS, as in the present study. They report a measured $\mathrm{O}: \mathrm{C}$ ratio of $0.33-0.48$ for remote ambient aerosol in the Austrian Alps.

PTR-MS measurements may underestimate $\mathrm{O}: \mathrm{C}$ ratios because of several factors, including charring and fragmentation due to ionisation; see Sect. S4. Holzinger et al. (2010a) assessed in detail how oxygen loss - common in PTR-MS measurements - lowers $\mathrm{O}: \mathrm{C}$ ratios. However, this was not taken into account for data reported here. 


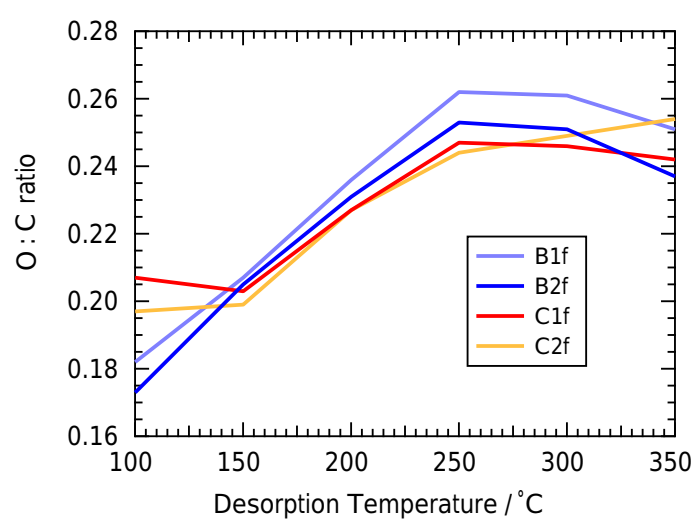

Figure 5. Measured oxygen-to-carbon ratios $(\mathrm{O}: \mathrm{C})$ of $\alpha$-pinene SOA desorbing from filters at different temperatures.

\subsection{Isotopic composition}

\subsubsection{Total carbon and thermally desorbed material}

Figure 6, panel (a), shows the isotopic composition of total carbon on the filters relative to the isotopic composition of the precursor $\alpha$-pinene. The aerosol on all front filters is enriched in carbon 13 relative to the initial $\alpha$-pinene, and the enrichment is larger for filter B1f (1.2\%o) than for filters C1f $(0.6 \%$ ) and $\mathrm{C} 2 \mathrm{f}(0.7 \%$ ). Compounds desorbing from back filter $\mathrm{C} 2 \mathrm{~b}$, which very likely represent gas-phase material, are depleted by $0.8 \%$.

Figure $6 \mathrm{~b}$ shows $\Delta\left({ }^{13} \mathrm{C}\right)$ of thermally desorbed filter material as a function of desorption temperature. Aerosol on the front filters shows a ${ }^{13} \mathrm{C}$ enrichment of $0.2-2.8 \%$ relative to the initial compound. The most volatile fraction that desorbed at $100^{\circ} \mathrm{C}$ consistently shows the highest enrichment. SOA compounds desorbing at $100^{\circ} \mathrm{C}$ are enriched in ${ }^{13} \mathrm{C}$ compared to $150{ }^{\circ} \mathrm{C}$ by about 0.7 to $1.9 \%$; see Table 2 . The $\Delta\left({ }^{13} \mathrm{C}\right)$ values of SOA do not change significantly with temperature at desorption temperatures above $150^{\circ} \mathrm{C}$. SOA formed in the presence of 1-butanol (filter B1f) is enriched by an additional $0.2-1.3 \%$ o compared to SOA formed in the presence of cyclohexane (filters C1f and $\mathrm{C} 2 \mathrm{f}$ ). The higher enrichment observed for SOA formed in the presence of 1butanol scavenger relative to cyclohexane scavenger may be because the latter has a higher SOA yield. This is corroborated by the PTRMS data; see Table 2 . The gas-phase compounds desorbing at $150^{\circ} \mathrm{C}$ from back filter $\mathrm{B} 1 \mathrm{~b}$ are depleted by $0.7 \%$ compared to the initial $\alpha$-pinene and depleted by $1.9 \%$ with respect to the particulate SOA on filter B1f. This is expected due to isotopic mass balance. The isotopic enrichment of gas-phase compounds on filter B1b at 100 and $350^{\circ} \mathrm{C}$ is similar to that of the corresponding particulate matter on front filter B1f. The low concentrations detected on the back filters at these desorption temperatures preclude any in-depth discussion of the enrichment seen at those temperatures.

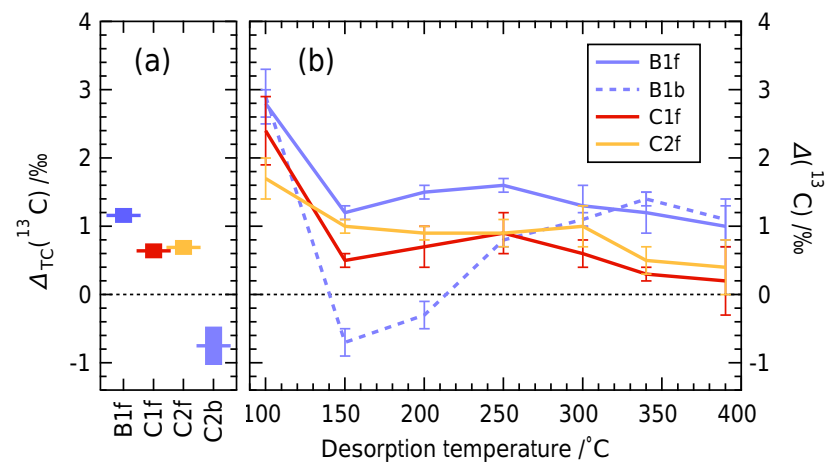

Figure 6. $\Delta\left({ }^{13} \mathrm{C}\right)$ values of alpha-pinene SOA filter samples. Full lines represent front filters, and dashed lines back filters. Error bars denote 1- $\sigma$ standard deviations and are propagated; they vary with loading. (a) TC analysis of selected filters (see $x$ axis). (b) Thermal desorption analysis of filter material.

Values of $\Delta_{\mathrm{TC}}\left({ }^{13} \mathrm{C}\right)$ are close to $\Delta\left({ }^{13} \mathrm{C}\right)$ values at $150{ }^{\circ} \mathrm{C}$ (Fig. 6 and Table 2). Values of $\Delta_{\mathrm{TC}}\left({ }^{13} \mathrm{C}\right)$ represent a convolution of the volume-normalised peak area and $\Delta\left({ }^{13} \mathrm{C}\right)$, with a dominant contribution of $\Delta\left({ }^{13} \mathrm{C}\right)$ at $150^{\circ} \mathrm{C}$. Total carbon analysis, however, misses details like the enrichment of the most volatile mass fraction desorbing at $100^{\circ} \mathrm{C}$.

\subsubsection{Position-specific isotope analysis of $\alpha$-pinene}

Table 1 lists $\Delta_{i}\left({ }^{13} \mathrm{C}\right)$ for each $\mathrm{C}$ atom of all analysed $\alpha$ pinene samples. Single sites show variations between -6.9 and $10.5 \%$. The $\alpha$-pinene samples from manufacturers Sigma-Aldrich (different lot from SOA experiments), Acros Organics, and Merck have similar position-specific isotope profiles. It is likely that these three manufacturers sell $\alpha$ pinene with the same origin (e.g. natural) and use similar preparation techniques. The last sample (from Alfa Aesar) has a slightly different profile which would seem to indicate a different origin and/or purification method. Samples of $\alpha$-pinene from Acros Organics $(j=3)$ and Merck $(j=4)$ have similar $\Delta_{i}\left({ }^{13} \mathrm{C}\right)$ profiles but differ by $1.1 \%$ in their bulk value.

Unfortunately, PSIA could not be performed on the $\alpha$ pinene used in chamber experiments (it was used up and is no longer available from the manufacturer). The $\alpha$-pinene used in chamber experiments has a bulk isotopic composition of $\delta_{\mathrm{TC}}^{\circ 1}\left({ }^{13} \mathrm{C}\right)=(-29.96 \pm 0.08) \%$, which differs by up to $3 \%$ from the other $\alpha$-pinene samples; see Table 1 . Given that the bulk isotopic composition is not correlated with the position-specific isotope profiles, and assuming that the manufacturer did not change product origin or purification method, it is probable that the two $\alpha$-pinene samples from Sigma-Aldrich share similar position-specific isotope profiles. It is therefore assumed for the remainder of the discussion that the $\alpha$-pinene used for the SOA experiments has the same position-specific isotope profile as the batch from 
Table 5. Calculated $\Delta\left({ }^{13} \mathrm{C}\right)$ values, assuming that fragmentation yields certain $\mathrm{C}$ atoms to be expelled to the gas phase and others to partition to the aerosol phase (details in Sect. 4.1). Calculations based on position-specific measurement results of the SigmaAldrich sample in Table 1. See Fig. 7 for numbering of $\mathrm{C}$ atoms.

\begin{tabular}{lrr}
\hline Expelled C atom(s) & $\Delta_{\text {gas }}\left({ }^{13} \mathrm{C}\right)(\% \circ)$ & $\Delta_{\text {aerosol }}\left({ }^{13} \mathrm{C}\right) /(\% \circ)$ \\
\hline $\mathrm{C}_{1}$ & 4.9 & -0.4 \\
$\mathrm{C}_{2}$ & 10.5 & -1.1 \\
$\mathrm{C}_{7}$ & 0.6 & 0.0 \\
$\mathrm{C}_{9}$ & -6.7 & 0.8 \\
$\mathrm{C}_{8}+\mathrm{C}_{1}+\mathrm{C}_{9}$ & -0.7 & 0.4 \\
$\mathrm{C}_{10}+\mathrm{C}_{1}+\mathrm{C}_{9}$ & -2.0 & 1.0 \\
\hline
\end{tabular}

Sigma-Aldrich on which PSIA was performed. The $\Delta_{i}\left({ }^{13} \mathrm{C}\right)$ distribution of that sample is visualised in Fig. 7.

\section{Discussion}

In this experiment we have run $\alpha$-pinene ozonolysis to completion and analysed the SOA and some of the gas-phase material. After comparing the IR-MS (Fig. 6) analysis with the PTRMS data (Fig. 5), we found that $\Delta\left({ }^{13} \mathrm{C}\right)$ does not show a correlation with the $\mathrm{O}: \mathrm{C}$ ratio. The PTRMS data showed that the isotopic enrichment in the SOA is carried by a broad range of oxidation products rather than one or a few dominant products. We argue that the observed isotopic abundancies are largely due to a combination of isotope-dependent changes in product branching ratios and unequal partitioning of carbon atoms from specific sites in $\alpha$-pinene into the aerosol and gas phases. Additional effects could include isotope-dependent variations in partitioning of semi-volatile compounds between the gas and condensed phases.

\subsection{Can position-specific isotope analysis of $\alpha$-pinene explain the enriched aerosol phase?}

Here, a limiting case is presented for the isotopic difference of a number of plausible oxidation products. The underlying assumptions exclude isotope-dependent changes in product branching ratios, as well as effects of temperature, relative humidity, pressure, ozone concentration, etc. This simplistic approach allows for the estimation of the maximum isotopic enrichment in $\alpha$-pinene fragments using the $\Delta_{i}\left({ }^{13} \mathrm{C}\right)$ profiles obtained from PSIA. Table 5 shows predicted maximal enrichments or depletions if a single carbon atom or reasonable combinations of three carbon atoms are split off the parent compound. Based on the chemical reaction pathways presented in Fig. 1, volatile reaction products such as acetone, $\mathrm{CO}$, and formaldehyde can reasonably be assigned to specific sites in the parent $\alpha$-pinene. The minor (potentially gaseous) expelled fragment is predicted to have an overall isotopic difference relative to the initial $\alpha$ -
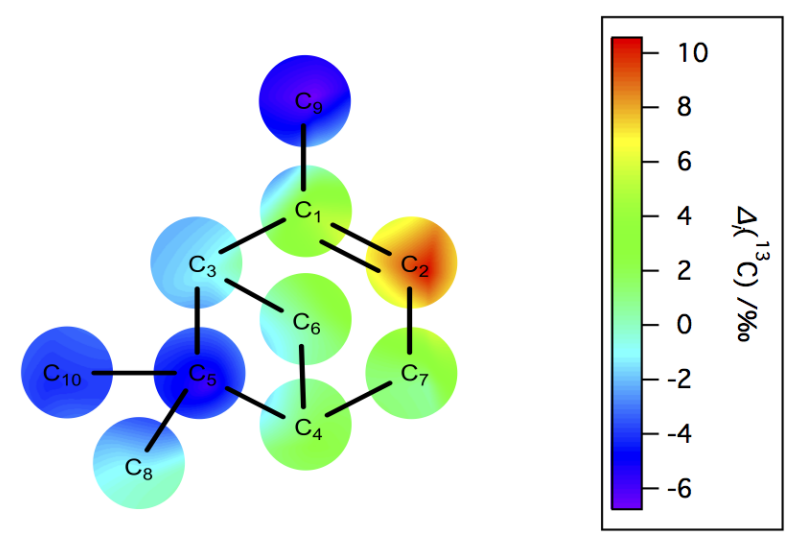

Figure 7. Heat map of $\Delta_{i}\left({ }^{13} \mathrm{C}\right)$ in $\alpha$-pinene (Sigma-Aldrich, lot MKBQ6213V) relative to its bulk isotopic composition; see Table 1 . The boundary of the image was set to $\Delta_{i}\left({ }^{13} \mathrm{C}\right)=0$, i.e. the bulk isotopic composition. A large enrichment is visible at the double bond $\left(\mathrm{C}_{2}\right)$, and large depletions are visible at positions $\mathrm{C}_{5}$ and $\mathrm{C}_{9}$ where isotopic substitution is expected to reduce the molar volume significantly. $\mathrm{C}$ atoms are numbered in order of decreasing ${ }^{13} \mathrm{C}$ chemical shifts in the ${ }^{13} \mathrm{C}$ NMR spectrum.

pinene, $\Delta_{\text {gas }}\left({ }^{13} \mathrm{C}\right)$, similar to the measured $\Delta_{i}\left({ }^{13} \mathrm{C}\right)$ value for the carbon atom's former position, as seen in Fig. 7. The larger fragment, which would partition to the aerosol phase, is predicted to have an overall $\Delta_{\text {aerosol }}\left({ }^{13} \mathrm{C}\right)$ value equal to the average of the $\Delta_{i}\left({ }^{13} \mathrm{C}\right)$ values of the remaining $\mathrm{C}$ atoms. For example, the pathway leading to formaldehyde in the sixth box in Fig. 1 is predicted to deplete formaldehyde by $\Delta_{9}\left({ }^{13} \mathrm{C}\right)=6.7 \%$ relative to the initial compound and leave the corresponding major fragment (denoted as " $R$ " in Fig. 1) enriched by $\left[\Delta_{i}\left({ }^{13} \mathrm{C}\right)\right]_{\mathrm{av}(i=1-8,10)}=0.8 \%$. Here, $[\ldots]_{\mathrm{av}(i=1-8,10)}$ denotes the mean of $\Delta_{i}\left({ }^{13} \mathrm{C}\right)$ values for $\mathrm{C}$ atoms 1-8 and 10. Expelled $\mathrm{C}$ atoms from positions with small $\Delta_{i}\left({ }^{13} \mathrm{C}\right)$ values, e.g. $\mathrm{C}_{7}$, will only have a small impact on the isotopic composition of the remaining fragment. For expulsion of $\mathrm{C}_{2}$, a depletion of $-1.1 \%$ is predicted for the aerosol fragment relative to the initial $\alpha$-pinene.

If three carbon atoms are expelled, as in the case of acetone, the enrichment of the minor fragment relative to the initial $\alpha$-pinene is calculated as the average of the $\Delta_{i}\left({ }^{13} \mathrm{C}\right)$ values of the respective expelled positions $\mathrm{C}_{8}, \mathrm{C}_{1}, \mathrm{C}_{9}$ or $\mathrm{C}_{10}$, $\mathrm{C}_{1}$, and $\mathrm{C}_{9}$; see Fig. 1. The formation of acetone may involve methyl migration of either the $\mathrm{C}_{8}$ or $\mathrm{C}_{10}$ atom. The gaseous fragments composed of three carbon atoms are predicted to show $\Delta_{\text {gas }}\left({ }^{13} \mathrm{C}\right)$ values of -0.7 and $-2.0 \%$, and the corresponding $\Delta_{\text {aerosol }}\left({ }^{13} \mathrm{C}\right)$ values for the larger fragment are 0.4 and 1.0\%o; see Table 5. These calculations are based on the measured position-specific enrichment for sample 2 in Table 1, but the results and conclusions drawn do not change significantly when performing similar calculations for the other $\alpha$-pinene samples where PSIA data are available (with the exception of the anomalous Alfa Aesar sample). 


\subsection{Branching ratios and other isotope effects}

The observed ${ }^{13} \mathrm{C}$ enrichment in compounds from the front filters (SOA) and the depletion in compounds from the back filters (gas phase) are generally larger or equal in magnitude to those predicted by position-specific isotope effect analysis (see Table 5). The data shown in Table 5 are limiting values and show that PSIA is capable, in principle, of producing abundances of similar magnitude to what was observed in our experiment. This mechanism does not include concomitant enrichment due to isotope effects on product branching ratios.

The other explanations include isotope-dependent changes in branching ratios in the reaction mechanism (Fig. 1) and incomplete reactions. It has been shown previously in simple systems (e.g. evaporation of solvents and sorption of vanillin) that each carbon position can have its own isotopic fractionation and that different positions can show opposing isotope effects at the same time (Höhener et al., 2012; Julien et al., 2015). In chemical reactions, the substitution of a ${ }^{12} \mathrm{C}$ atom by ${ }^{13} \mathrm{C}$ will affect isomerisation and stabilisation dynamics by changing vibrational frequencies with an associated change in zero point energies. Therefore, positions that are not reaction sites can also show isotope effects, which have been termed non-covalent isotope effects (Wade, 1999), as has been observed during the chain-shortening reaction for the bioconversion of ferulic acid to vanillin (Botosoa et al., $2009 b$ ). It is generally difficult to predict which position has which isotope effect, but it has been shown that isotopic substitution in ring structures at positions that carry functional groups lead to stronger position-specific isotope effects compared to positions that have no functional groups attached (Höhener et al., 2012; Botosoa et al., 2009b). Similarly, the $\mathrm{C}$ atoms in $\alpha$-pinene that are not part of the ring structure might have large position-specific isotope effects. Höhener et al. (2012) note that, for vanillin, such effects can produce large fractionations in the small fragments and small fractionations in the large fragments, similar to what we show in Table 5. Accordingly, in $\alpha$-pinene there is about an order of magnitude difference between the site-dependent enrichments seen in the $\mathrm{C}_{10}$ molecule (6-10\%o) and the enrichments seen in the SOA $(0.6-1.2 \%$ ).

Kinetic isotope effects associated with fragmentation provide a possible explanation for the enrichment of the particle phase with respect to the gas phase. After the first two reaction steps (i.e. formation of the Criegee intermediate and the subsequent decomposition, stabilisation, or isomerisation of it; see Fig. 1) the products will be distributed between the gas and particle phases according to their respective partitioning coefficients. This partitioning is not expected to lead to significant isotopic fractionation within a chemical species. A number of these products are small volatile compounds that partition to the gas phase. The remaining particle phase would be enriched, which is consistent with observations reported previously (Aggarwal and Kawamura, 2008; Kirillova et al., 2013, 2014). Fragmentation followed by functionalisation is expected to be accompanied by elevated $\mathrm{O}: \mathrm{C}$ ratios in both products, as detailed in the introduction. This is in line with the observed increasing $\mathrm{O}: \mathrm{C}$ ratios of desorbed material from front filters at increasing desorption temperatures below $250^{\circ} \mathrm{C}$ (Fig. 5), and with $\mathrm{O}: \mathrm{C}$ ratios that are generally elevated for back filter material desorbing at all temperatures (Table 2).

Large equilibrium fractionation due to gas-particle partitioning could also explain the observations, given that individual compounds might show isotope effects of $1-2 \%$ due to partial volatilisation. In an ensemble of compounds, however, most individual compounds are likely to be found predominantly in one phase; only a fraction of products have intermediate volatilities. In the case of $\alpha$-pinene ozonolysis shown in Fig. 1, small first generation products like $\mathrm{CO}$, $\mathrm{HCHO}$, and acetone will be gaseous and the larger entities, including prominent acids, will partition to particles due to their lower vapour pressure. Ongoing reactions (e.g. dimer formation and oligomerisation) will lower their vapour pressure even further. Equilibrium isotope effects of single compounds are therefore diluted and hence less likely to cause the observed isotopic enrichment in SOA.

The present study allows new insight to be gained into observations of isotopically enriched ambient SOA. In some cases isotopic enrichment in ambient aerosol was attributed to photochemical ageing during long-range transport (Kirillova et al., 2013; Pavuluri et al., 2011). However, Fu et al. (2012) note that a normal kinetic isotope effect cannot explain their observation of aerosol that was even more enriched than aerosol from biomass burning. The authors noted that such aerosol occurred predominantly during the day during episodes of high abundance of biogenic SOA. The present study suggests that the site-specific distribution of ${ }^{13} \mathrm{C}$ in the source material itself governs the abundance of ${ }^{13} \mathrm{C}$ in SOA.

\section{Conclusions}

The isotopic and chemical compositions of SOA generated from dark ozonolysis of $\alpha$-pinene were determined using isotope ratio mass spectrometry and thermal-desorption PTRMS, and PSIA was applied for the first time on $\alpha$-pinene from a series of manufacturers. A key result is the first observations of strong site-dependent enrichments and depletions in ${ }^{13} \mathrm{C}$ in $\alpha$-pinene, with values between -6.9 and $+10.5 \%$ relative to the bulk composition. Total carbon from SOA collected on front filters was enriched in ${ }^{13} \mathrm{C}$ by $0.6-1.2 \%$ o with respect to the initial $\alpha$-pinene precursor. Total carbon adsorbed on the back filters, designed to sample gas-phase compounds, was depleted by $-0.8 \%$.

High-resolution data retrieved by a PTR-MS detected more than 400 ions. More than $90 \%$ of the total desorbed mass as measured by PTR-MS (from front filters) was un- 
ambiguously identified and discussed in the context of the current literature. SOA mainly desorbed from the filters at $150{ }^{\circ} \mathrm{C}$, and larger compounds likely formed in oligomerisation reactions decomposed during extraction or ionisation. Besides the fragments from such oligomers, single constituents of complex organic mixtures formed on the filter were also detected as single ions of lower mass which show significant non-zero concentrations at desorption temperatures higher than $150^{\circ} \mathrm{C}$. The observed constant $\mathrm{O}: \mathrm{C}$ ratio at desorption temperatures exceeding $250{ }^{\circ} \mathrm{C}$ also indicates fragments of larger molecules. At lower temperatures the $\mathrm{O}: \mathrm{C}$ ratio increases from 0.18 to 0.25 , indicating functionalisation reactions during SOA formation. A comparison of the IR-MS results with the PTRMS data shows that $\Delta\left({ }^{13} \mathrm{C}\right)$ does not correlate with the $\mathrm{O}: \mathrm{C}$ ratio.

Analysis of the isotopic composition as a function of desorption temperature showed that the isotopic composition of material desorbing at $150^{\circ} \mathrm{C}$ was similar to the isotopic composition of total carbon. Functionalisation typically follows fragmentation in monoterpene ozonolysis and was shown to drive the $\mathrm{O}: \mathrm{C}$ temperature profiles. The partitioning of products between the gas and condensed phases is an active area of research, and both chemical and physical effects must be considered. The partitioning is not simply governed by vapour pressure; some gas-phase products may be incorporated into SOA through oligomerisation. Many variables, including product branching ratios, temperature, pressure, humidity, $\mathrm{OH}, \mathrm{NO}_{x}$, etc., can in principle have an effect on the isotopic abundance of ${ }^{13} \mathrm{C}$ in SOA and this leaves room for further studies. The present study suggests that the sitespecific distribution of ${ }^{13} \mathrm{C}$ in the source material itself governs the abundance of ${ }^{13} \mathrm{C}$ in SOA.

Data availability. The archive is publicly available at: http://www.erda.dk/public/archives/YXJjaGl2ZS16OVF4em0= /published-archive.html (Johnson, 2017).

\section{The Supplement related to this article is available online at doi:10.5194/acp-17-6373-2017-supplement.}

Competing interests. The authors declare that they have no conflict of interest.

Acknowledgements. The authors thank IntraMIF and the University of Copenhagen for supporting this research. The research has received funding from the European Commission's Seventh Framework Programme (FP7/2007-2013) under grant agreement number 237890 . The thermogram ${ }^{13} \mathrm{C}$ analysis was funded by the Netherlands Organisation for Scientific Research (NWO), grant number 820.01.001.
Edited by: M. C. Facchini

Reviewed by: three anonymous referees

\section{References}

Aggarwal, S. G. and Kawamura, K.: Molecular distributions and stable carbon isotopic compositions of dicarboxylic acids and related compounds in aerosols from Sapporo, Japan: Implications for photochemical aging during long-range atmospheric transport, J. Geophys. Res. Atmos., 113, D14301, doi:10.1029/2007JD009365, 2008.

Aiken, A. C., DeCarlo, P. F., Kroll, J. H., Worsnop, D. R., Huffman, J. A., Docherty, K. S., Ulbrich, I. M., Mohr, C., Kimmel, J. R., Sueper, D., Sun, Y., Zhang, Q., Trimborn, A., Northway, M., Ziemann, P. J., Canagaratna, M. R., Onasch, T. B., Alfarra, M. R., Prevot, A. S. H., Dommen, J., Duplissy, J., Metzger, A., Baltensperger, U., and Jimenez, J. L.: O/C and OM/OC Ratios of Primary, Secondary, and Ambient Organic Aerosols with HighResolution Time-of-Flight Aerosol Mass Spectrometry, Environ. Sci. Technol., 42, 4478-4485, doi:10.1021/es703009q, 2008.

Andreae, M. O. and Crutzen, P. J.: Atmospheric Aerosols: Biogeochemical Sources and Role in Atmospheric Chemistry, Science, 276, 1052-1058, doi:10.1126/science.276.5315.1052, 1997.

Bayle, K., Akoka, S., Remaud, G. S., and Robins, R. J.: NonStatistical 13C Distribution during Carbon Transfer from Glucose to Ethanol During Fermentation is Determined by the Catabolic Pathway Exploited, J. Biol. Chem., 290, 4118-4128, doi:10.1074/jbc.M114.621441, 2014a.

Bayle, K., Gilbert, A., Julien, M., Yamada, K., Silvestre, V., Robins, R. J., Akoka, S., Yoshida, N., and Remaud, G. S.: Conditions to obtain precise and true measurements of the intramolecular $13 \mathrm{C}$ distribution in organic molecules by isotopic $13 \mathrm{C}$ nuclear magnetic resonance spectrometry, Anal. Chim. Acta., 846, 1-7, doi:10.1016/j.aca.2014.07.018, 2014b.

Botosoa, E. P., Caytan, E., Silvestre, V., Robins, R. J., Akoka, S., and Remaud, G. S.: Unexpected Fractionation in Site-Specific 13C Isotopic Distribution Detected by Quantitative 13C NMR at Natural Abundance, J. Am. Chem. Soc., 130, 414-415, doi:10.1021/ja0771181, 2008.

Botosoa, E. P., Blumenstein, C., MacKenzie, D. A., Silvestre, V., Remaud, G. S., Kwiecień, R. A., and Robins, R. J.: Quantitative isotopic $13 \mathrm{C}$ nuclear magnetic resonance at natural abundance to probe enzyme reaction mechanisms via site-specific isotope fractionation: The case of the chain-shortening reaction for the bioconversion of ferulic acid to vanillin, Anal. Biochem., 393, 182-188, doi:10.1016/j.ab.2009.06.031, 2009a.

Botosoa, E. P., Silvestre, V., Robins, R. J., Rojas, J. M. M., Guillou, C., and Remaud, G. S.: Evidence of $13 \mathrm{C}$ non-covalent isotope effects obtained by quantitative $13 \mathrm{C}$ nuclear magnetic resonance spectroscopy at natural abundance during normal phase liquid chromatography, J. Chromatogr. A, 1216, 7043-7048, doi:10.1016/j.chroma.2009.08.066, 2009b.

Brooks, P. D., Geilmann, H., Werner, R. A., and Brand, W. A.: Improved precision of coupled $\mathrm{d} 13 \mathrm{C}$ and $\mathrm{d} 15 \mathrm{~N}$ measurements from single samples using an elemental analyzer/isotope ratio mass spectrometer combination with a post-column six-port valve and selective $\mathrm{CO}_{2}$ trapping; improved halide robustness of the com- 
bustion reactor using $\mathrm{CeO} 2$, Rapid Commun. Mass Sp., 17, 1924-1926, doi:10.1002/rcm.1134, 2003.

Camredon, M., Hamilton, J. F., Alam, M. S., Wyche, K. P., Carr, T., White, I. R., Monks, P. S., Rickard, A. R., and Bloss, W. J.: Distribution of gaseous and particulate organic composition during dark a-pinene ozonolysis, Atmos. Chem. Phys., 10, 2893-2917, doi:10.5194/acp-10-2893-2010, 2010.

Cappa, C. D., Lovejoy, E. R., and Ravishankara, A. R.: Evidence for liquid-like and nonideal behavior of a mixture of organic aerosol components, P. Natl. Acad. Sci. USA, 105, 1868718691, doi:10.1073/pnas.0802144105, 2008.

Ceburnis, D., Garbaras, A., Szidat, S., Rinaldi, M., Fahrni, S., Perron, N., Wacker, L., Leinert, S., Remeikis, V., Facchini, M. C., Prevot, A. S. H., Jennings, S. G., Ramonet, M., and O'Dowd, C. D.: Quantification of the carbonaceous matter origin in submicron marine aerosol by ${ }^{13} \mathrm{C}$ and ${ }^{14} \mathrm{C}$ isotope analysis, Atmos. Chem. Phys., 11, 8593-8606, doi:10.5194/acp-11-85932011, 2011.

Chacon-Madrid, H. J. and Donahue, N. M.: Fragmentation vs. functionalization: chemical aging and organic aerosol formation, Atmos. Chem. Phys., 11, 10553-10563, doi:10.5194/acp11-10553-2011, 2011.

Cheng, Y. and He, K.: Uncertainties in observational data on organic aerosol: An annual perspective of sampling artifacts in Beijing, China, Environ. Pollut., 206, 113-121, doi:10.1016/j.envpol.2015.06.012, 2015.

Coplen, T. B.: Guidelines and recommended terms for expression of stable-isotope-ratio and gas-ratio measurement results, Rapid Commun. Mass Sp., 25, 2538-2560, doi:10.1002/rcm.5129, 2011.

Coplen, T. B., Brand, W. A., Gehre, M., Gröning, M., Meijer, H. A. J., Toman, B., and Verkouteren, R. M.: New Guidelines for d13C Measurements, Anal. Chem., 78, 2439-2441, doi:10.1021/ac052027c, 2006.

Docherty, K. S. and Ziemann, P. J.: Effects of Stabilized Criegee Intermediate and $\mathrm{OH}$ Radical Scavengers on Aerosol Formation from Reactions of beta-Pinene with $\mathrm{O}_{3}$, Aerosol Sci. Tech., 37, 877-891, doi:10.1080/02786820300930, 2003.

Docherty, K. S., Wu, W., Lim, Y. B., and Ziemann, P. J.: Contributions of Organic Peroxides to Secondary Aerosol Formed from Reactions of Monoterpenes with $\mathrm{O}_{3}$, Environ. Sci. Technol., 39, 4049-4059, doi:10.1021/es050228s, 2005.

Dockery, D. W., Pope, C. A., Xu, X., Spengler, J. D., Ware, J. H., Fay, M. E., Ferris, B. G., and Speizer, F. E.: An Association between Air Pollution and Mortality in Six U.S. Cities, New Engl. J. Med., 329, 1753-1759, doi:10.1056/NEJM199312093292401, 1993.

Donahue, N. M., Robinson, A. L., Stanier, C. O., and Pandis, S. N.: Coupled Partitioning, Dilution, and Chemical Aging of Semivolatile Organics, Environ. Sci. Technol., 40, 2635-2643, doi:10.1021/es052297c, 2006.

Donahue, N. M., Epstein, S. A., Pandis, S. N., and Robinson, A. L.: A two-dimensional volatility basis set: 1. organic-aerosol mixing thermodynamics, Atmos. Chem. Phys., 11, 3303-3318, doi:10.5194/acp-11-3303-2011, 2011.

Dusek, U., Meusinger, C., Oyama, B., Ramon, W., de Wilde, P., Holzinger, R., and Röckmann, T.: A thermal desorption system for measuring d13C ratios on organic aerosol, J. Aerosol Sci., 66, 72-82, doi:10.1016/j.jaerosci.2013.08.005, 2013.
Emanuelsson, E. U., Watne, A. K., Lutz, A., Ljungstrom, E., and Hallquist, M.: Influence of Humidity, Temperature, and Radicals on the Formation and Thermal Properties of Secondary Organic Aerosol (SOA) from Ozonolysis of beta-Pinene, J. Phys. Chem. A, 117, 10346-10358, doi:10.1021/jp4010218, 2013.

Emanuelsson, E. U., Mentel, T. F., Watne, A. K., Spindler, C., Bohn, B., Brauers, T., Dorn, H.-P., Hallquist, A. M., Haseler, R., Kiendler-Scharr, A., Müller, K.-P., Pleijel, H., Rohrer, F., Rubach, F., Schlosser, E., Tillmann, R., and Hallquist, M.: Parameterization of Thermal Properties of Aging Secondary Organic Aerosol Produced by Photo-Oxidation of Selected Terpene Mixtures, Environ. Sci. Technol., 48, 6168-6176, doi:10.1021/es405412p, 2014.

Fisseha, R., Saurer, M., Jäggi, M., Siegwolf, R. T. W., Dommen, J., Szidat, S., Samburova, V., and Baltensperger, U.: Determination of primary and secondary sources of organic acids and carbonaceous aerosols using stable carbon isotopes, Atmos. Environ., 43, 431-437, doi:10.1016/j.atmosenv.2008.08.041, 2009.

Fu, P. Q., Kawamura, K., Chen, J., Li, J., Sun, Y. L., Liu, Y., Tachibana, E., Aggarwal, S. G., Okuzawa, K., Tanimoto, H., Kanaya, Y., and Wang, Z. F.: Diurnal variations of organic molecular tracers and stable carbon isotopic composition in atmospheric aerosols over Mt. Tai in the North China Plain: an influence of biomass burning, Atmos. Chem. Phys., 12, 8359-8375, doi:10.5194/acp-12-8359-2012, 2012.

Gao, S., Ng, N. L., Keywood, M., Varutbangkul, V., Bahreini, R., Nenes, A., He, J., Yoo, K. Y., Beauchamp, J. L., Hodyss, R. P., Flagan, R. C., and Seinfeld, J. H.: Particle Phase Acidity and Oligomer Formation in Secondary Organic Aerosol, Environ. Sci. Technol., 38, 6582-6589, doi:10.1021/es049125k, 2004.

Gensch, I., Laumer, W., Stein, O., Kammer, B., Hohaus, T., Saathoff, H., Wegener, R., Wahner, A., and Kiendler-Scharr, A.: Temperature dependence of the kinetic isotope effect in beta-pinene ozonolysis, J. Geophys. Res., 116, D20301, doi:10.1029/2011JD016084, 2011.

Gilbert, A., Silvestre, V., Segebarth, N., Tcherkez, G., Guillou, C., Robins, R. J., Akoka, S., and Remaud, G. S.: The intramolecular 13C-distribution in ethanol reveals the influence of the $\mathrm{CO}_{2}$-fixation pathway and environmental conditions on the sitespecific 13C variation in glucose, Plant Cell Environ., 34, 1104 1112, doi:10.1111/j.1365-3040.2011.02308.x, 2011.

Gilbert, A., Hattori, R., Silvestre, V., Wasano, N., Akoka, S., Hirano, S., Yamada, K., Yoshida, N., and Remaud, G. S.: Comparison of IRMS and NMR spectrometry for the determination of intramolecular 13C isotope composition: Application to ethanol, Talanta, 99, 1035-1039, doi:10.1016/j.talanta.2012.05.023, 2012

Hänninen, O. O., Alm, S., Katsouyanni, K., Künzli, N., Maroni, M., Nieuwenhuijsen, M. J., Saarela, K., Srám, R. J., Zmirou, D., and Jantunen, M. J.: The EXPOLIS study: implications for exposure research and environmental policy in Europe, J. Expo. Sci. Env. Epid., 14, 440-456, doi:10.1038/sj.jea.7500342, 2004.

Hall, W. A. and Johnston, M. V.: The ThermalStability of Oligomers in Alpha-Pinene Secondary Organic Aerosol, Aerosol Sci. Technol., 46, 983-989,. doi:10.1080/02786826.2012.685114, 2012.

Hallquist, M., Wenger, J. C., Baltensperger, U., Rudich, Y., Simpson, D., Claeys, M., Dommen, J., Donahue, N. M., George, C., Goldstein, A. H., Hamilton, J. F., Herrmann, H., Hoff- 
mann, T., Iinuma, Y., Jang, M., Jenkin, M. E., Jimenez, J. L., Kiendler-Scharr, A., Maenhaut, W., McFiggans, G., Mentel, Th. F., Monod, A., Prévôt, A. S. H., Seinfeld, J. H., Surratt, J. D., Szmigielski, R., and Wildt, J.: The formation, properties and impact of secondary organic aerosol: current and emerging issues, Atmos. Chem. Phys., 9, 5155-5236, doi:10.5194/acp-9-51552009, 2009.

Ho, K. F., Lee, S. C., Cao, J. J., Li, Y. S., Chow, J. C., Watson, J. G., and Fung, K.: Variability of organic and elemental carbon, water soluble organic carbon, and isotopes in Hong Kong, Atmos. Chem. Phys., 6, 4569-4576, doi:10.5194/acp-6-4569-2006, 2006.

Holzinger, R.: PTRwid: A new widget tool for processing PTR-TOF-MS data, Atmos. Meas. Tech., 8, 3903-3922, doi:10.5194/amt-8-3903-2015, 2015.

Holzinger, R., Lee, A., Paw, K. T., and Goldstein, U. A. H.: Observations of oxidation products above a forest imply biogenic emissions of very reactive compounds, Atmos. Chem. Phys., 5, 67-75, doi:10.5194/acp-5-67-2005, 2005.

Holzinger, R., Kasper-Giebl, A., Staudinger, M., Schauer, G., and Röckmann, T.: Analysis of the chemical composition of organic aerosol at the Mt. Sonnblick observatory using a novel high mass resolution thermal-desorption proton-transfer-reaction mass-spectrometer (hr-TD-PTR-MS), Atmos. Chem. Phys., 10, 10111-10128, doi:10.5194/acp-10-10111-2010, 2010a.

Holzinger, R., Williams, J., Herrmann, F., Lelieveld, J., Donahue, N. M., and Röckmann, T.: Aerosol analysis using a ThermalDesorption Proton-Transfer-Reaction Mass Spectrometer (TDPTR-MS): a new approach to study processing of organic aerosols, Atmos. Chem. Phys., 10, 2257-2267, doi:10.5194/acp10-2257-2010, 2010b.

Holzinger, R., Goldstein, A. H., Hayes, P. L., Jimenez, J. L., and Timkovsky, J.: Chemical evolution of organic aerosol in Los Angeles during the CalNex 2010 study, Atmos. Chem. Phys., 13, 10125-10141, doi:10.5194/acp-13-10125-2013, 2013.

Huang, L., Brook, J., Zhang, W., Li, S., Graham, L., Ernst, D., Chivulescu, A., and Lu, G.: Stable isotope measurements of carbon fractions (OC/EC) in airborne particulate: A new dimension for source characterization and apportionment, Atmos. Environ., 40, 2690-2705, doi:10.1016/j.atmosenv.2005.11.062, 2006.

Höhener, P., Silvestre, V., Lefrançois, A., Loquet, D., Botosoa, E. P., Robins, R. J., and Remaud, G. S.: Analytical model for site-specific isotope fractionation in $13 \mathrm{C}$ during sorption: Determination by isotopic 13C NMR spectrometry with vanillin as model compound, Chemosphere, 87, 445-452, doi:10.1016/j.chemosphere.2011.12.023, 2012.

Iannone, R., Koppmann, R., and Rudolph, J.: Stable carbon kinetic isotope effects for the production of methacrolein and methyl vinyl ketone from the gas-phase reactions of isoprene with ozone and hydroxyl radicals, Atmos. Environ., 44, 41354141, doi:10.1016/j.atmosenv.2010.07.046, 2010.

Irei, S., Rudolph, J., Huang, L., Auld, J., and Hastie, D.: Stable carbon isotope ratio of secondary particulate organic matter formed by photooxidation of toluene in indoor smog chamber, Atmos. Environ., 45, 856-862, doi:10.1016/j.atmosenv.2010.11.021, 2011.

Irei, S., Takami, A., Hayashi, M., Sadanaga, Y., Hara, K., Kaneyasu, N., Sato, K., Arakaki, T., Hatakeyama, S., Bandow, H., Hikida, T., and Shimono, A.: Transboundary Secondary Organic Aerosol in Western Japan Indicated by the $\delta^{13} \mathrm{C}$ of Water-Soluble Organic Carbon and the $\mathrm{m} / \mathrm{z} 44$ Signal in Organic Aerosol Mass Spectra, Environ. Sci. Technol., 48, 6273-6281, doi:10.1021/es405362y, 2014.

Isaacman-VanWertz, G., Yee, L. D., Kreisberg, N. M., Wernis, R., Moss, J. A., Hering, S. V., de Sá, S. S., Martin, Scot T., Alexander, M. L., Palm, B. B., Hu, W., Campuzano-Jost, P., Day, D. A., Jimenez, J. L., Riva, M., Surratt, J. D., Viegas, J., Manzi, A., Edgerton, E., Baumann, K., Souza, R., Artaxo, P., and Goldstein, A. H.: Ambient gas-particle partitioning of tracers for biogenic oxidation, Environ. Sci. Technol., 18, 9952-9962, doi:10.1021/acs.est.6b01674, 2016.

Jaoui, M. and Kamens, R. M.: Gaseous and Particulate Oxidation Products Analysis of a Mixture of $\alpha$-pinene $+\beta$-pinene $/ \mathrm{O}_{3} / \mathrm{Air}$ in the Absence of Light and $\alpha$-pinene $+\beta$-pinene/ $\mathrm{NO}_{x} /$ Air in the Presence of Natural Sunlight, J. Atmos. Chem., 44, 259-297, doi:10.1023/A:1022977427523, 2003.

Jenkin, M. E.: Modelling the formation and composition of secondary organic aerosol from $\alpha$ - and $\beta$-pinene ozonolysis using MCM v3, Atmos. Chem. Phys., 4, 1741-1757, doi:10.5194/acp4-1741-2004, 2004.

Jimenez, J. L., Canagaratna, M. R., Donahue, N. M., Prevot, A. S. H., Zhang, Q., Kroll, J. H., DeCarlo, P. F., Allan, J. D., Coe, H., Ng, N. L., Aiken, A. C., Docherty, K. S., Ulbrich, I. M., Grieshop, A. P., Robinson, A. L., Duplissy, J., Smith, J. D., Wilson, K. R., Lanz, V. A., Hueglin, C., Sun, Y. L., Tian, J., Laaksonen, A., Raatikainen, T., Rautiainen, J., Vaattovaara, P., Ehn, M., Kulmala, M., TomLinson, J. M., Collins, D. R., Cubison, M. J., E, Dunlea, J., Huffman, J. A., Onasch, T. B., Alfarra, M. R., Williams, P. I., Bower, K., Kondo, Y., Schneider, J., Drewnick, F., Borrmann, S., Weimer, S., Demerjian, K., Salcedo, D., Cottrell, L., Griffin, R., Takami, A., Miyoshi, T., Hatakeyama, S., Shimono, A., Sun, J. Y., Zhang, Y. M., Dzepina, K., Kimmel, J. R., Sueper, D., Jayne, J. T., Herndon, S. C., Trimborn, A. M., Williams, L. R., Wood, E. C., Middlebrook, A. M., Kolb, C. E., Baltensperger, U., and Worsnop, D. R.: Evolution of Organic Aerosols in the Atmosphere, Science, 326, 1525-1529, doi:10.1126/science.1180353, 2009.

Johnson, M. S.: Data files for Meusinger et al. alpha pinene SOA paper ACP 2017, available at: http://www.erda.dk/public/archives/ YXJjaGl2ZS16OVF4em0=/published-archive.html, 2017.

Johnson, M. S., Feilberg, K. L., von Hessberg, P., and Nielsen, O. J.: Isotopic processes in atmospheric chemistry, Chem. Soc. Rev., 31, 313-323, doi:10.1039/b108011n, 2002.

Julien, M., Parinet, J., Nun, P., Bayle, K., Höhener, P., Robins, R. J., and Remaud, G. S.: Fractionation in position-specific isotope composition during vaporization of environmental pollutants measured with isotope ratio monitoring by $13 \mathrm{C}$ nuclear magnetic resonance spectrometry, Environ. Pollut., 205, 299306, doi:10.1016/j.envpol.2015.05.047, 2015.

Kalberer, M., Paulsen, D., Sax, M., Steinbacher, M., Dommen, J., Prevot, A. S. H., Fisseha, R., Weingartner, E., Frankevich, V., Zenobi, R., and Baltensperger, U.: Identification of Polymers as Major Components of Atmospheric Organic Aerosols, Science, 303, 1659-1662, doi:10.1126/science.1092185, 2004.

Kalberer, M., Sax, M., and Samburova, V.: Molecular Size Evolution of Oligomers in Organic Aerosols Collected in Urban Atmospheres and Generated in a Smog Chamber, Environ. Sci. Technol., 40, 5917-5922, doi:10.1021/es0525760, 2006. 
Keywood, M. D., Kroll, J. H., Varutbangkul, V., Bahreini, R., Flagan, R. C., and Seinfeld, J. H.: Secondary Organic Aerosol Formation from Cyclohexene Ozonolysis: Effect of $\mathrm{OH}$ Scavenger and the Role of Radical Chemistry, Environ. Sci. Technol., 38, 3343-3350, doi:10.1021/es049725j, 2004.

King, S. M., Rosenoern, T., Shilling, J. E., Chen, Q., and Martin, S. T.: Increased cloud activation potential of secondary organic aerosol for atmospheric mass loadings, Atmos. Chem. Phys., 9, 2959-2971, doi:10.5194/acp-9-2959-2009, 2009.

King, S. M., Butcher, A. C., Rosenørn, T., Coz, E., Lieke, K. I., de Leeuw, G., Nilsson, E. D., and Bilde, M.: Investigating Primary Marine Aerosol Properties: CCN Activity of Sea Salt and Mixed Inorganic-Organic Particles, Environ. Sci. Technol., 46, 10 405-10 412, doi:10.1021/es300574u, 2012.

Kirillova, E. N., Andersson, A., Sheesley, R. J., Kruså, M., Praveen, P. S., Budhavant, K., Safai, P. D., Rao, P. S. P., and Gustafsson, O.: 13C- and 14C-based study of sources and atmospheric processing of water-soluble organic carbon (WSOC) in South Asian aerosols, J. Geophys. Res.-Atmos., 118, 614-626, doi:10.1002/jgrd.50130, 2013.

Kirillova, E. N., Andersson, A., Han, J., Lee, M., and Gustafsson, Ö.: Sources and light absorption of water-soluble organic carbon aerosols in the outflow from northern China, Atmos. Chem. Phys., 14, 1413-1422, doi:10.5194/acp-14-1413-2014, 2014.

Kleindienst, T., Smith, D., Li, W., Edney, E., Driscoll, D., Speer, R., and Weathers, W.: Secondary organic aerosol formation from the oxidation of aromatic hydrocarbons in the presence of dry submicron ammonium sulfate aerosol, Atmos. Environ., 33, 36693681, doi:10.1016/S1352-2310(99)00121-1, 1999.

Kristensen, K., Watne, Å. K., Hammes, J., Lutz, A., Petäjä, T., Hallquist, M., Bilde, M., and Glasius, M.: High-Molecular Weight Dimer Esters Are Major Products in Aerosols from $\alpha$-Pinene Ozonolysis and the Boreal Forest, Environ. Sci. Technol. Lett., 3, 280-285, doi:10.1021/acs.estlett.6b00152, 2016.

Kroll, J. H. and Seinfeld, J. H.: Chemistry of secondary organic aerosol: Formation and evolution of low-volatility organics in the atmosphere, Atmos. Environ., 42, 3593-3624, doi:10.1016/j.atmosenv.2008.01.003, 2008.

Kroll, J. H., Smith, J. D., Che, D. L., Kessler, S. H., Worsnop, D. R., and Wilson, K. R.: Measurement of fragmentation and functionalization pathways in the heterogeneous oxidation of oxidized organic aerosol, Phys. Chem. Chem. Phys., 11, 8005-8014, doi:10.1039/B905289E, 2009.

Kroll, J. H., Donahue, N. M., Jimenez, J. L., Kessler, S. H., Canagaratna, M. R., Wilson, K. R., Altieri, K. E., Mazzoleni, L. R., Wozniak, A. S., Bluhm, H., Mysak, E. R., Smith, J. D., Kolb, C. E., and Worsnop, D. R.: Carbon oxidation state as a metric for describing the chemistry of atmospheric organic aerosol, Nat. Chem., 3, 133-139, doi:10.1038/nchem.948, 2011.

Lopez-Hilfiker, F. D., Mohr, C., D’Ambro, E. L., Lutz, A., Riedel, T. P., Gaston, C. J., Iyer, S., Zhang, Z., Gold, A., Surratt, J. D., Lee, B. H., Kurten, T., Hu, W. W., Jimenez, J., Hallquist, M., and Thornton, J. A.: Molecular Composition and Volatility of Organic Aerosol in the Southeastern U.S.: Implications for IEPOX Derived SOA, Environ. Sci. Technol., 5, 2200-2209, doi:10.1021/acs.est.5b04769, 2016.

Masalaite, A., Remeikis, V., Garbaras, A., Dudoitis, V., Ulevicius, V., and Ceburnis, D.: Elucidating carbonaceous aerosol sources by the stable carbon d13CTC ratio in size-segregated particles, Atmos. Res., 158-159, 1-12, doi:10.1016/j.atmosres.2015.01.014, 2015.

Miyazaki, Y., Fu, P. Q., Kawamura, K., Mizoguchi, Y., and Yamanoi, K.: Seasonal variations of stable carbon isotopic composition and biogenic tracer compounds of water-soluble organic aerosols in a deciduous forest, Atmos. Chem. Phys., 12, 13671376, doi:10.5194/acp-12-1367-2012, 2012.

Narukawa, M., Kawamura, K., Li, S.-M., and Bottenheim, J. W.: Stable carbon isotopic ratios and ionic composition of the high-Arctic aerosols: An increase in d13C values from winter to spring, J. Geophys. Res.-Atmos., 113, D02312, doi:10.1029/2007JD008755, 2008.

O’Dowd, C., Ceburnis, D., Ovadnevaite, J., Vaishya, A., Rinaldi, M., and Facchini, M. C.: Do anthropogenic, continental or coastal aerosol sources impact on a marine aerosol signature at Mace Head?, Atmos. Chem. Phys., 14, 10687-10704, doi:10.5194/acp-14-10687-2014, 2014.

Pavuluri, C. M., Kawamura, K., Swaminathan, T., and Tachibana, E.: Stable carbon isotopic compositions of total carbon, dicarboxylic acids and glyoxylic acid in the tropical Indian aerosols: Implications for sources and photochemical processing of organic aerosols, J. Geophys. Res.-Atmos., 116, D18307, doi:10.1029/2011JD015617, 2011.

Presto, A. A. and Donahue, N. M.: Investigation of alpha-Pinene + Ozone Secondary Organic Aerosol Formation at Low Total Aerosol Mass, Environ. Sci. Technol., 40, 3536-3543, doi:10.1021/es052203z, 2006.

Rudich, Y., Donahue, N. M., and Mentel, T. F.: Aging of Organic Aerosol: Bridging the Gap Between Laboratory and Field Studies, Annu. Rev. Phys. Chem., 58, 321-352, doi:10.1146/annurev.physchem.58.032806.104432, 2007.

Rudolph, J. and Czuba, E.: On the use of isotopic composition measurements of volatile organic compounds to determine the "photochemical age" of an air mass, Geophys. Res. Lett., 27, 38653868, doi:10.1029/2000GL011385, 2000.

Rudolph, J., Czuba, E., and Huang, L.: The stable carbon isotope fractionation for reactions of selected hydrocarbons with $\mathrm{OH}$ radicals and its relevance for atmospheric chemistry, J. Geophys. Res., 105, 29329-29346, 2000.

Sakugawa, H. and Kaplan, I. R.: Stable carbon isotope measurements of atmospheric organic acids in Los Angeles, California, Geophys. Res. Lett., 22, 1509-1512, doi:10.1029/95GL01359, 1995.

Shilling, J. E., Chen, Q., King, S. M., Rosenoern, T., Kroll, J. H., Worsnop, D. R., McKinney, K. A., and Martin, S. T.: Particle mass yield in secondary organic aerosol formed by the dark ozonolysis of $\alpha$-pinene, Atmos. Chem. Phys., 8, 2073-2088, doi:10.5194/acp-8-2073-2008, 2008.

Silvestre, V., Mboula, V. M., Jouitteau, C., Akoka, S., Robins, R. J., and Remaud, G. S.: Isotopic 13C NMR spectrometry to assess counterfeiting of active pharmaceutical ingredients: Site-specific 13C content of aspirin and paracetamol, J. Pharmaceut. Biomed., 50, 336-341, doi:10.1016/j.jpba.2009.04.030, 2009.

Stocker, T. F., Qin, D., Plattner, G.-K., Tignor, M., Allen, S. K., Boschung, J., Nauels, A., Xia, Y., Bex, V., and Midgley, P. (Eds.): IPCC, 2013: Climate Change 2013: The Physical Science Basis. Contribution of Working Group I to the Fifth Assessment Report of the Intergovernmental Panel on Climate Change, Cambridge 
University Press, Cambridge, United Kingdom and New York, NY, USA, 2013.

Subramanian, R., Khlystov, A. Y., Cabada, J. C., and Robinson, A. L.: Positive and Negative Artifacts in Particulate Organic Carbon Measurements with Denuded and Undenuded Sampler Configurations, Aerosol Sci. Tech., 38, 27-48, doi:10.1080/02786820390229354, 2004.

Timkovsky, J., Dusek, U., Henzing, J. S., Kuipers, T. L., Röckmann, T., and Holzinger, R.: Offline thermal-desorption proton-transfer-reaction mass spectrometry to study composition of organic aerosol, J. Aerosol Sci., 79, 1-14, doi:10.1016/j.jaerosci.2014.08.010, 2015.

Tolocka, M. P., Jang, M., Ginter, J. M., Cox, F. J., Kamens, R. M., and Johnston, M. V.: Formation of Oligomers in Secondary Organic Aerosol, Environ. Sci. Technol., 38, 1428-1434, doi:10.1021/es035030r, 2004.

Turekian, V. C., Macko, S. A., and Keene, W. C.: Concentrations, isotopic compositions, and sources of size-resolved, particulate organic carbon and oxalate in near-surface marine air at Bermuda during spring, J. Geophys. Res., 108, 4157, doi:10.1029/2002JD002053, 2003.

Turpin, B. J., Saxena, P., and Andrews, E.: Measuring and simulating particulate organics in the atmosphere: problems and prospects, Atmos. Environ., 34, 2983-3013, 2000.

Wade, D.: Deuterium isotope effects on noncovalent interactions between molecules, Chemico-Biological Interactions, 117, 191217, doi:10.1016/S0009-2797(98)00097-0, 1999.
Watson, J. G., Chow, J. C., Chen, L.-W. A., and Frank, N. H.: Methods to Assess Carbonaceous Aerosol Sampling Artifacts for IMPROVE and Other Long-Term Networks, J. Air Waste Manage., 59, 898-911, doi:10.3155/1047-3289.59.8.898, 2009.

Werner, R. A. and Brand, W. A.: Referencing strategies and techniques in stable isotope ratio analysis, Rapid Commun. Mass Sp. 15, 501-519, doi:10.1002/rcm.258, 2001.

Werner, R. A., Bruch, B. A., and Brand, W. A.: ConFlo III - an interface for high precision $\mathrm{d} 13 \mathrm{C}$ and $\mathrm{d} 15 \mathrm{~N}$ analysis with an extended dynamic range, Rapid Commun. Mass Sp., 13, 1237-1241, doi:10.1002/(SICI)1097-0231(19990715)13:13<1237::AIDRCM633>3.0.CO;2-C, 1999.

Widory, D., Roy, S., Le Moullec, Y., Goupil, G., Cocherie, A., and Guerrot, C.: The origin of atmospheric particles in Paris: a view through carbon and lead isotopes, Atmos. Environ., 38, 953-961, doi:10.1016/j.atmosenv.2003.11.001, 2004.

Williams, E. L. and Grosjean, D.: Removal of atmospheric oxidants with annular denuders, Environ. Sci. Technol., 24, 811814, doi:10.1021/es00076a002, 1990.

Winterhalter, R., Van Dingenen, R., Larsen, B. R., Jensen, N. R., and Hjorth, J.: LC-MS analysis of aerosol particles from the oxidation of $\alpha$-pinene by ozone and OH-radicals, Atmos. Chem. Phys. Discuss., 3, 1-39, doi:10.5194/acpd-3-1-2003, 2003.

Witter, M., Berndt, T., Böge, O., Stratmann, F., and Heintzenberg, J.: Gas-phase ozonolysis: Rate coefficients for a series of terpenes and rate coefficients and $\mathrm{OH}$ yields for 2-methyl-2-butene and 2,3-dimethyl-2-butene, Int. J. Chem. Kinet., 34, 394-403, doi:10.1002/kin.10063, 2002. 